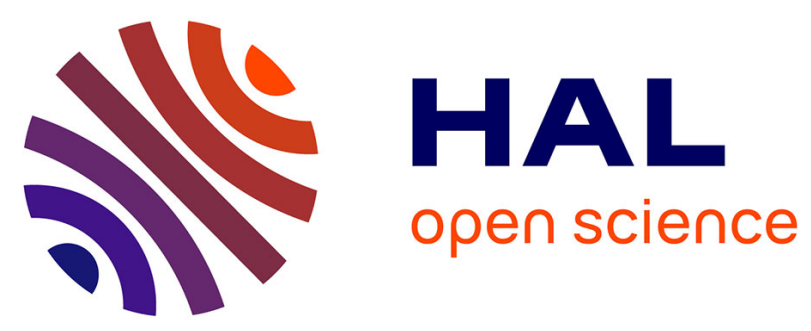

\title{
Synthesis, Characterization, and DFT Analysis of Bis-Terpyridyl-Based Molecular Cobalt Complexes
}

Safwan Aroua, Tanya K. Todorova, Paul Hommes, Lise-Marie Chamoreau, Hans-Ulrich Reissig, Victor Mougel, Marc Fontecave

\section{To cite this version:}

Safwan Aroua, Tanya K. Todorova, Paul Hommes, Lise-Marie Chamoreau, Hans-Ulrich Reissig, et al.. Synthesis, Characterization, and DFT Analysis of Bis-Terpyridyl-Based Molecular Cobalt Complexes. Inorganic Chemistry, 2017, 56 (10), pp.5930-5940. 10.1021/acs.inorgchem.7b00595 . hal-01522899

\section{HAL Id: hal-01522899 \\ https://hal.sorbonne-universite.fr/hal-01522899}

Submitted on 15 May 2017

HAL is a multi-disciplinary open access archive for the deposit and dissemination of scientific research documents, whether they are published or not. The documents may come from teaching and research institutions in France or abroad, or from public or private research centers.
L'archive ouverte pluridisciplinaire HAL, est destinée au dépôt et à la diffusion de documents scientifiques de niveau recherche, publiés ou non, émanant des établissements d'enseignement et de recherche français ou étrangers, des laboratoires publics ou privés. 


\title{
Synthesis, Characterisation and DFT Analysis of Bisterpyridyl-Based Molecular Cobalt Complexes
}

\author{
Safwan Aroua, ${ }^{a}$ Tanya K. Todorova, ${ }^{a}$ Paul Hommes, ${ }^{b}$ Lise-Marie Chamoreau, ${ }^{c}$ Hans-Ulrich \\ Reissig, ${ }^{b}$ Victor Mougel, ${ }^{a}$ Marc Fontecave*a
}

a Laboratoire de Chimie des Processus Biologiques, UMR 8229 CNRS, Collège de France, Université Paris 6, 11 Place Marcelin Berthelot, 75231 Paris Cedex 05 (France)

${ }^{\mathrm{b}}$ Institut für Chemie und Biochemie, Freie Universität Berlin, Takustrasse 3, 14195 Berlin (Germany)

c Sorbonne Universités, UPMC Université Paris 6, Institut Parisien de Chimie Moléculaire, UMR 8232 CNRS, 4 Place Jussieu, 75252 Paris Cedex 5 (France)

*e-mail: marc.fontecave@college-de-france.fr 


\section{ABSTRACT}

Terpyridine ligands are widely used in chemistry and material sciences owing to their ability to form stable molecular complexes with a large variety of metal ions. In that context, variations of the substituents on the terpyridine ligand allow to modulate the material properties. Applying the Stille cross-coupling reaction we prepared with good yields a new series of terpyridine ligands possessing quinoline-type moieties in ortho-, meta- and para-positions and dimethylamino substituents at central or distal positions. The corresponding cobalt(II) complexes were synthesized and fully characterized by elemental analysis, single crystal X-ray crystallography, mass spectrometry, UV-vis, ${ }^{1} \mathrm{H}-\mathrm{NMR}$ and Fourier Transform Infrared (FT-IR) spectroscopies as well as by cyclic voltammetry (CV). Density functional theory (DFT) calculations were performed to investigate the electronic structure of all the $\mathrm{Co}$ (II) bis-terpyridyl molecular complexes. In this work, we show that terpyridine ligand functionalization allows tuning the redox potentials of the $\mathrm{Co}(\mathrm{III}) / \mathrm{Co}(\mathrm{II}), \mathrm{Co}(\mathrm{II}) / \mathrm{Co}(\mathrm{I})$ and $\mathrm{Co}(\mathrm{I}) / \mathrm{Co}(\mathrm{I})(\mathrm{tpy}) \bullet-$ couples over a $1 \mathrm{~V}$ range.

\section{INTRODUCTION}

Molecular complexes containing a metal center and one or two terpyridine ligands have been extensively studied as photosensitizers, ${ }^{1}$ redox shuttles for Dye Sensitized Solar Cells (DSSC), ${ }^{2}$ anolytes for redox flow batteries, ${ }^{3}$ ion sensors, ${ }^{4}$ nanowire transistors, ${ }^{5}$ supramolecular polymers, ${ }^{6}$ but also for nonlinear optics, ${ }^{7}$ and catalysis for proton $^{8}$ and $\mathrm{CO}_{2}$ reduction. ${ }^{8 \mathrm{a},}{ }^{9}$ The properties of such complexes have been shown to be strongly influenced by the electronic nature of the terpyridine ligands. The potential applications of terpyridyl complexes as photosensitizers have been previously investigated by Damrauer and co-workers, using the iron complex, and by 
Berlinguette and co-workers, using ruthenium complexes. ${ }^{1}$ Limitations arise from the lack of efficient procedures to synthesize new terpyridine ligands, in particular bearing electronically different substituents, which is still a current research topic. ${ }^{10}$

Following the initial synthesis of terpyridine in 1932 by oxidative coupling of pyridine using anhydrous $\mathrm{FeCl}_{3}$ salt, ${ }^{11}$ several alternative synthetic routes have been employed, however with limited efficiency in terms of yield and selectivity. Syntheses based on $\operatorname{Pd}(0)$-catalyzed pyridine coupling ${ }^{12}$ or oxidation of diacetylpyridine, followed by a condensation with an $\alpha, \beta$-unsaturated aldehyde in the presence of ammonium acetate ${ }^{13}$ have been proposed. Such methods and other similar ones allowed to introduce aliphatic functional groups.

Syntheses using Hiyama, Suzuki and Stille cross-coupling reactions have recently been reported. ${ }^{14}$ In particular, the application of Stille cross-coupling for the preparation of terpyridines achieved in 1996 by Jean-Pierre Sauvage and co-workers ${ }^{14 c}$ allowed the isolation of a variety of substituted terpyridines. Surprisingly little has been done to study the electronic effects of these ligands on the physico-chemical properties of their metal complexes. ${ }^{8 \mathrm{a}}$

In this work, we have studied a new series of substituted terpyridine ligands $\mathbf{L 2}-\mathbf{L 8}$, shown in Figure 1, with the parent terpyridine ligand $\mathbf{L} \mathbf{1}$ as a reference. The introduced functional groups were chosen to allow investigating the influence of a broad range of electronic environments. Ligand $\mathbf{L 2}$ holds two highly antagonistic electronic groups, one electron-donating substituent (dimethylamino) on the central ring, and two electron-withdrawing substituents (trifluoromethyl) on the distal rings. $\mathbf{L} \mathbf{2}$ was chosen to investigate the influence of functionalization at the 4-distal position relative to the 4-central position, with special interest of compensating effects. Ligands L3 - L5 holding quinolines in three different orientations (L3: ortho, L4: meta, L5: para) were designed as compounds with potential ability to delocalize a negative charge. Ligands $\mathbf{L 6}-\mathbf{L 8}$ 
form a class of strongly electron-enriched dimethylamino-based terpyridines. The number of 4dimethylamino groups varied from one on the central ring in $\mathbf{L 6}$ to two on distal ones in $\mathbf{L 7}$ or one on each ring in L8. In addition, ligands L6 - L8 possess a methyl group at 2-position acting as a weak electron donor.

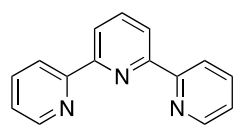

L1

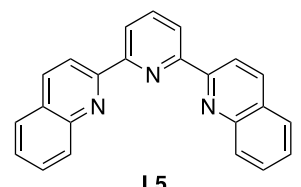

L5

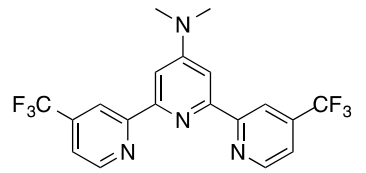

L2

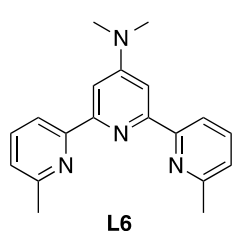

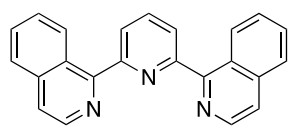

L3

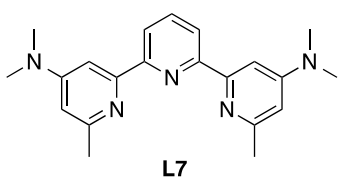

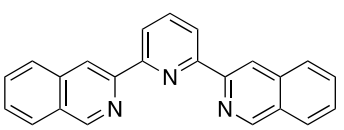

L4

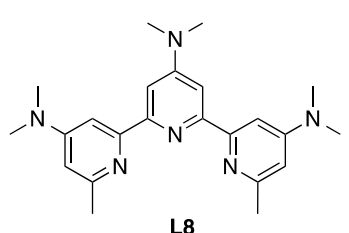

Figure 1. New terpyridine-based ligands prepared in this study (L1 is used as a reference).

The corresponding cobalt(II) bis-terpyridyl molecular complexes $\mathbf{C 1}-\mathbf{C 8}$ (Figure 2) were prepared and characterized by single-crystal X-ray diffraction, ${ }^{1} \mathrm{H}-\mathrm{NMR}$, FT-IR and UV-vis spectroscopies, mass spectrometry, cyclic voltammetry, as well as by DFT computations. This provides a means to determine the influence of the electronic effects of the terpyridine substituents on the physico-chemical properties of the complexes. 


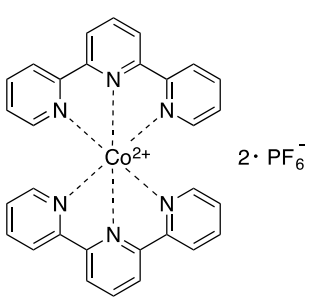

c1

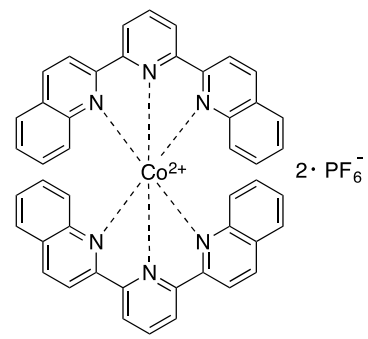

C5

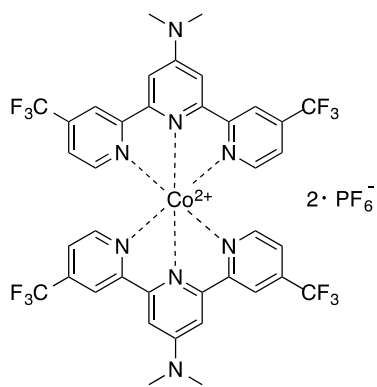

C2

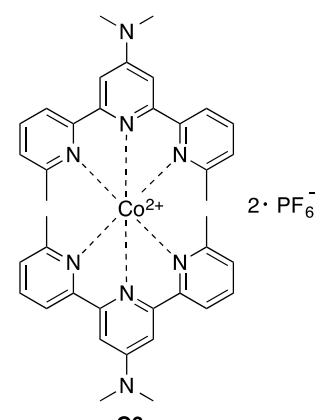

C6

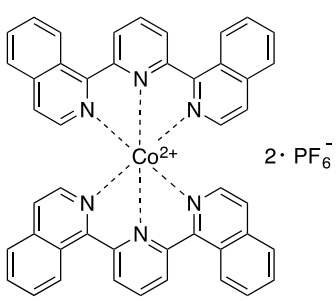

c3

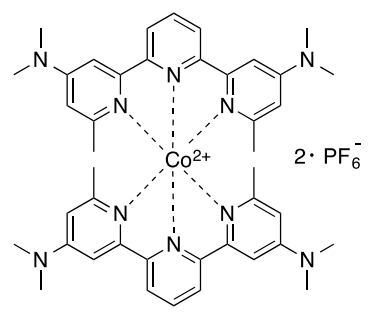

c7

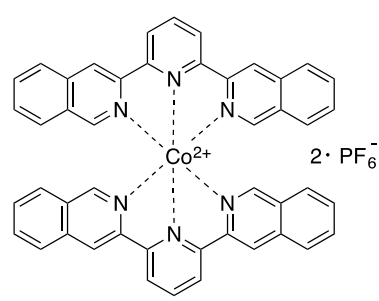

C4

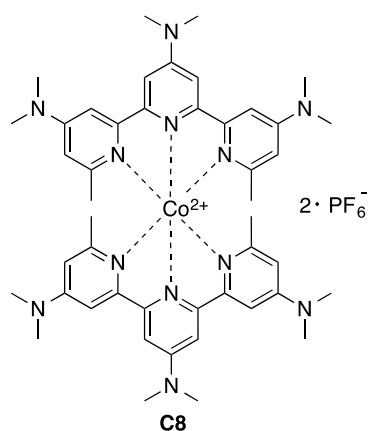

Figure 2. Cobalt bis-terpyridyl-based molecular complexes $(\mathbf{C 1}-\mathbf{C 8})$ investigated in this work.

\section{RESULTS AND DISCUSSSION}

Synthesis of substituted terpyridine ligands. Synthesis of the ligands using Hiyama, Negishi and Suzuki cross-coupling reactions proved unsuccessful, affording only traces of products. The various reaction conditions investigated are summarized in Scheme S3. Alternatively, we investigated a synthetic route based on the Stille cross-coupling reaction, as described in Figure 3. Two different strategies were followed: (i) for the preparation of quinoline derivatives (L3 L5), 2-(halo)-pyridine 1 was coupled to 2-(bisorganostannyl)-pyridine 2; (ii) for terpyridines holding a dimethylamino group on the central ring (L2, L5), 2-(organostannyl)-pyridine 3 was coupled to 2-(diiodo)-pyridine 4 (Figure 3). Both strategies provided sufficient amounts of product, with an isolated yield of $37-94 \%$. Ligands L7 and L8 holding distal dimethylamino 
groups were prepared according to previously reported procedures involving the coupling of 2,6pyridinedicarboxylic acid derivatives 5 with $\beta$-ketoenamine $\mathbf{6}$, a subsequent cyclocondensation reaction to 7 followed by activation and aromatic nucleophilic substitution. ${ }^{15}$

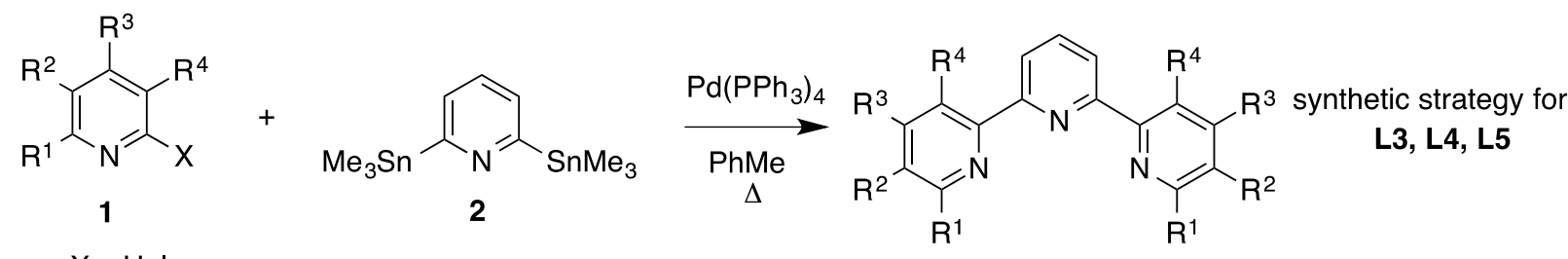

$\mathrm{X}=\mathrm{Hal}$
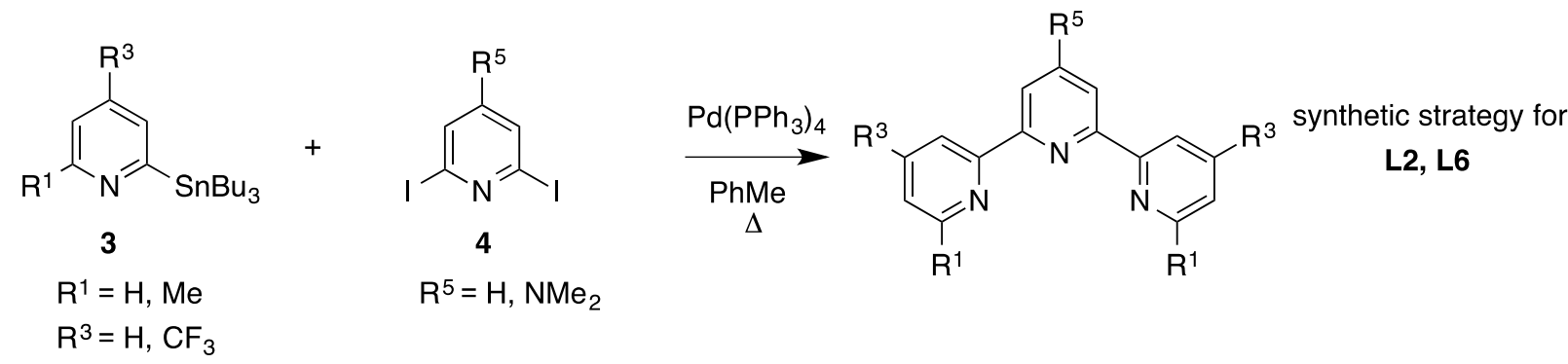

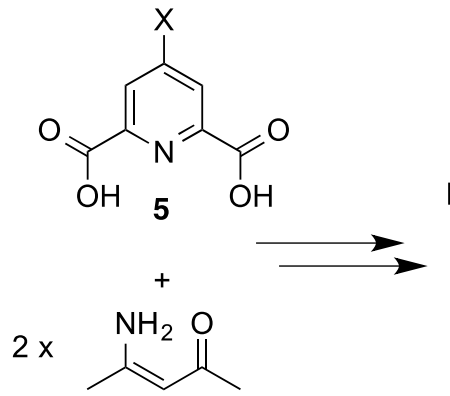

6<smiles>[R]c1cc(C)nc(-c2cc([X])cc(-c3cc(O)cc(C)n3)n2)c1</smiles>

$$
\mathrm{X}=\mathrm{H} \text {, Hal } \quad \mathrm{R}=\mathrm{H}, \mathrm{NMe}_{2}
$$

Figure 3. Synthetic strategies applied to obtain ligands $\mathbf{L 2}-\mathbf{L 8}$.

Synthesis of $\left.[\mathrm{Co} \text { (terpyridyl })_{2}\right]\left(\mathrm{PF}_{6}\right)_{2}$ complexes. The corresponding bis-substituted cobalt(II) complexes $\mathbf{C 1}-\mathbf{C 8}$ were obtained by reacting stoichiometric ratios of the ligand and cobalt dichloride in methanol under reflux followed by precipitation of the complex through anion exchange with ammonium hexafluorophosphate $\left(\mathrm{NH}_{4} \mathrm{PF}_{6}\right) \cdot{ }^{16}$ All complexes are paramagnetic as confirmed by their ${ }^{1} \mathrm{H}-\mathrm{NMR}$ spectra showing peaks at up to ca $120 \mathrm{ppm}$ (Figure S12 - S19). For all complexes the number of peaks in proton NMR at $300 \mathrm{~K}$ is consistent with a $C_{2 v}$ symmetry. 
The bands assigned to the ligands in the FT-IR spectra of complexes $\mathbf{C 1}-\mathbf{C 8}$ are characterized by significant shifts reflecting complexation with cobalt(II) (Figure S49). The electronic effects of the ligands can be nicely probed by UV-Vis spectroscopy: (i) the $\pi-\pi^{*}$ transition bands (allowed transitions) in the UV-vis spectra are red-shifted upon complexation with $\mathrm{Co}(\mathrm{II})$ (e.g. $\lambda_{\max } \mathbf{L 1}=277 \mathrm{~nm}, \lambda_{\max } \mathbf{C 1}=317 \mathrm{~nm}$, Figure S50 - S57) and (ii) light absorption by complexes C1 - C8 starts at much lower energy (ca. $500-600 \mathrm{~nm}$ ), as compared to the free ligands (below $400 \mathrm{~nm}$ ) (Figure S50 - S57).

Crystal structures. Crystals were obtained by slow evaporation of acetone - toluene (2:1 v:v) solutions of the complexes. The crystal structures were determined for $\mathbf{C 1}$ and $\mathbf{C 3}-\mathbf{C 8}$ (single crystals of C2 of sufficient quality could not be obtained) and are shown in Figure 4 (crystallographic parameters are given in Table S1 and S2). Distorted octahedral geometries (ML6) were found for all complexes, with two ligands per Co center and three nitrogen atoms of each ligand coordinating the cobalt(II) ion. For each complex, two hexafluorophosphate counter ions are present in the unit cell to balance the charges.

We first examined the structural changes induced by the different substituents on the ligands. We defined the orthogonality between the ligands in each complex by means of two parameters, i.e., the acute $\alpha$ and the obtuse $\beta \mathrm{N}_{\text {dist }}-\mathrm{Co}-\mathrm{N}_{\text {dist }}$ angles as shown in Figure 5(a). A difference between these two values reflects a deviation from orthogonality. The results are summarized in Table 1. While in complex $\mathbf{C 1}$, as well as in $\mathbf{C 4}, \mathbf{C} 7$ and $\mathbf{C 8}$, the angles $\alpha$ and $\beta$ have comparable values with differences $<3^{\circ}$, significant deviations are observed in the case of complexes $\mathbf{C 3}, \mathbf{C 5}$ and C6 (Table 1), with $\alpha$ and $\beta$ values of $89^{\circ}$ and $97^{\circ}$, respectively (C5), and $91^{\circ}$ and $96^{\circ}$, respectively (C3 and $\mathbf{C 6}$ ). The largest deviation was observed for complex $\mathbf{C 5}$ likely due to 
intermolecular $\pi-\pi$ interactions with neighboring complexes and co-crystallized toluene solvent molecules (see below).

Additionally, deviation from planarity of the ligands in these complexes was quantified using three descriptors, $d_{1}, d_{2}$ and $d_{3}$, (see Figure $5(b)$ ): they account for the deviation of each pyridyl ring with respect to a plane defined by the three nitrogen atoms of one ligand. The descriptors measure the corresponding distance between the plane and the 4-pyridyl position in each pyridyl ring (see Table 1).

C1
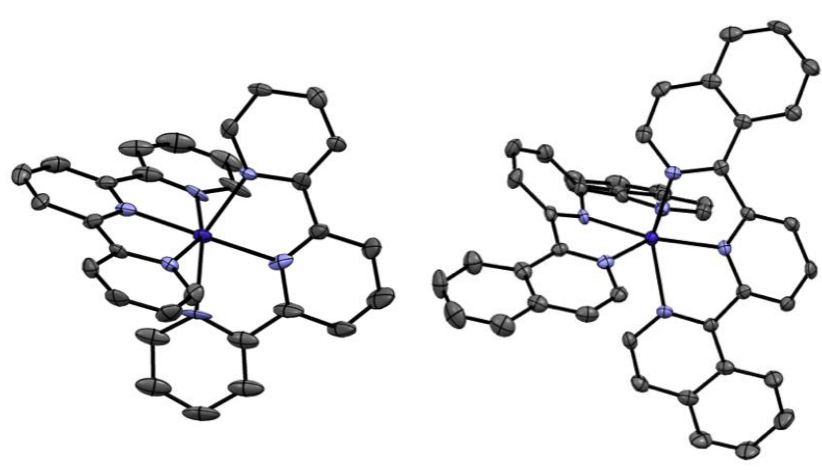

C4

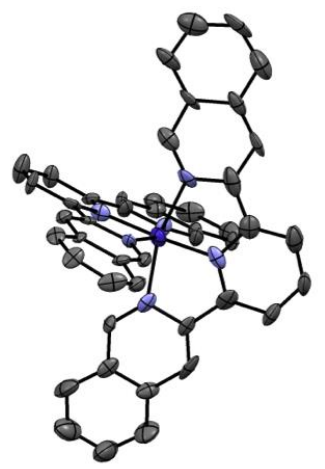

C5

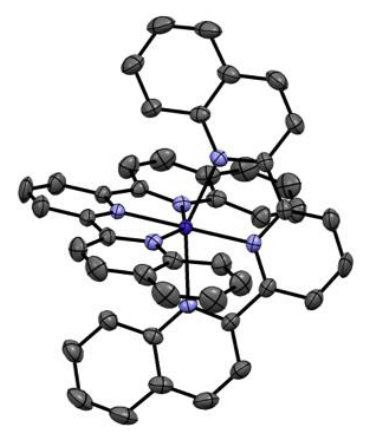

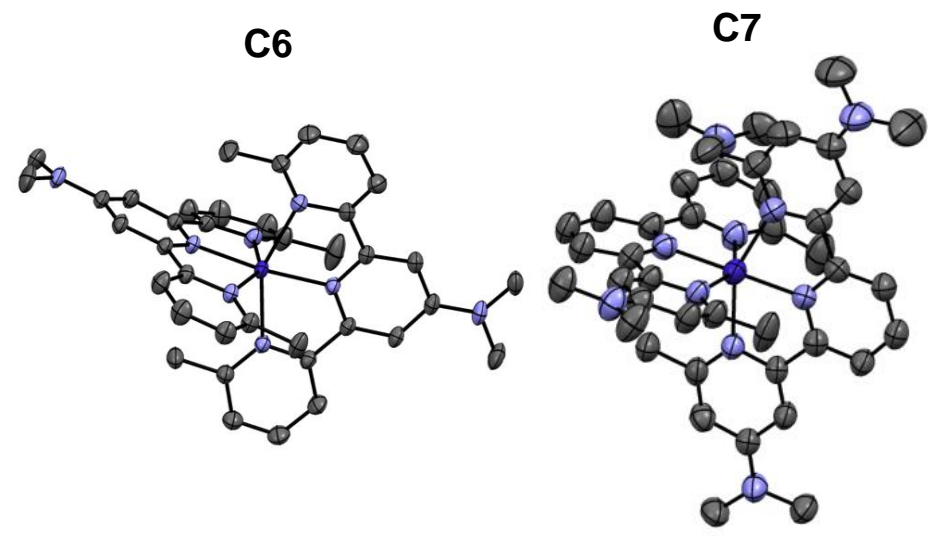

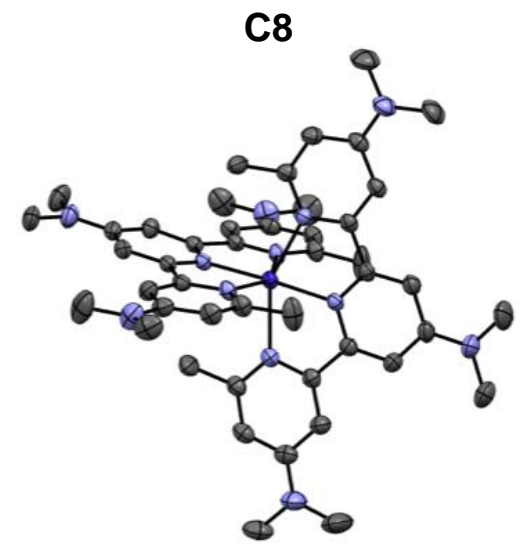

Figure 4. Crystal structures of molecular complexes $\mathbf{C 1}$ and $\mathbf{C 3}-\mathbf{C 8}$. Hexafluorophosphate counter-ions, hydrogen atoms and solvent molecules were omitted for clarity (Ellipsoid representations with $50 \%$ probability level). 

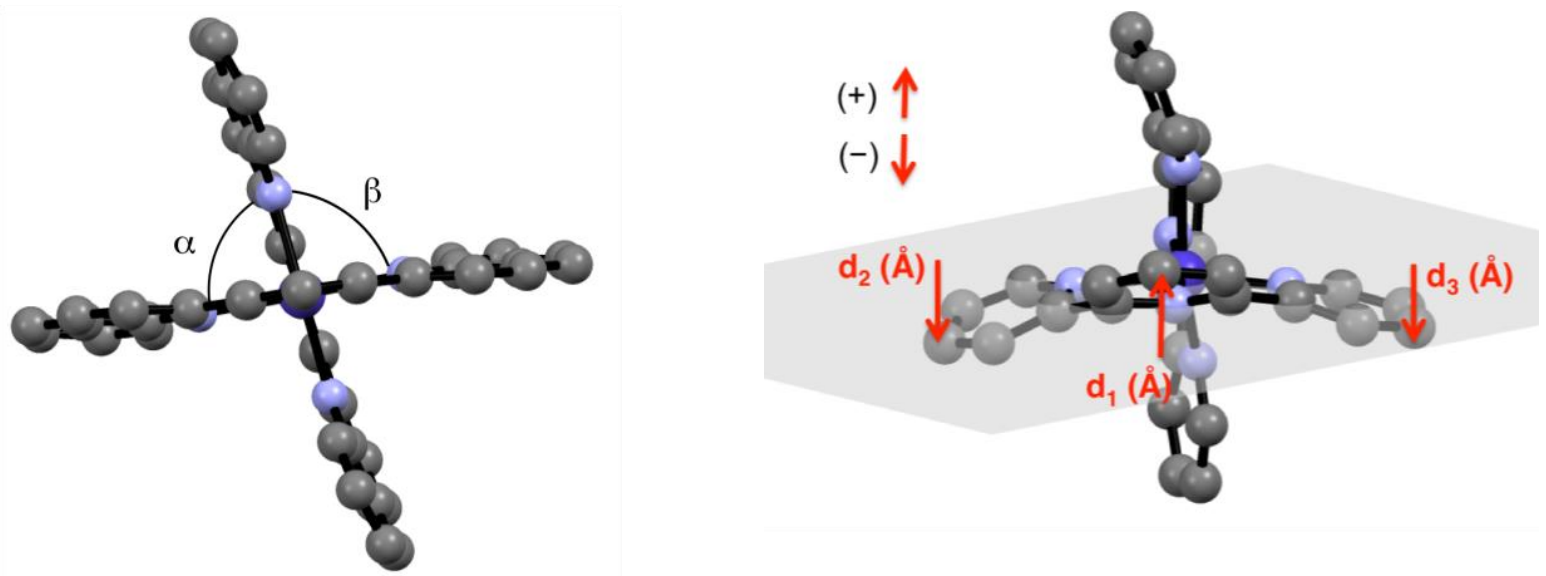

Figure 5. (a) Deviation from orthogonality descriptors: acute angle $\alpha$ and obtuse angle $\beta$ (averaged $\mathrm{N}_{\text {dist }}-\mathrm{Co}-\mathrm{N}_{\text {dist }}$ angles); (b) Deviation from planarity descriptors $\mathrm{d}_{1}, \mathrm{~d}_{2}, \mathrm{~d}_{3}$ (the three $\mathrm{N}$ atoms of the ligand define a plane). Arbitrarily, the central ring is always defined above the plane. Deviations above or below the plane are denoted with + and -, respectively. 
Table 1. Descriptors for the deviation from orthogonality ( $\alpha$ and $\beta$ in deg) and for the deviation from planarity $\left(\mathrm{d}_{1}, \mathrm{~d}_{2}, \mathrm{~d}_{3}\right.$ in $\AA$ ). Experimental and corresponding computed values (M06-L/6$311+\mathrm{G}(\mathrm{d}, \mathrm{p})$ level of theory, $0 \mathrm{~K})$ for both low-spin doublet and high-spin quartet spin states of complexes $\mathbf{C 1}-\mathbf{C 8}$ are reported. For C5, the computed values in parenthesis ()* are obtained from an optimized structure with four toluene solvent molecules, see Figure S75.

\begin{tabular}{|c|c|c|c|c|c|c|c|c|c|}
\hline & & C1 & $\mathrm{C} 2$ & C3 & C4 & C5 & C6 & $\mathrm{C} 7$ & C8 \\
\hline \multirow{5}{*}{$\begin{array}{l}\text { Experimental } \\
\text { (standard } \\
\text { deviation) }\end{array}$} & $\alpha(a v)$ & 93.15 & -- & 91.3 & 90.3 & 89.3 & 91.0 & 92.1 & 92.4 \\
\hline & $\beta(\mathrm{av})$ & 93.59 & -- & 96.0 & 92.6 & 97.3 & 95.8 & 94.5 & 94.5 \\
\hline & $d_{1}$ (av) & $+0.00(6)$ & -- & $+1.14(8)$ & $+0.2(1)$ & $+0.0(0)$ & $+0.13(0)$ & $+0.3(2)$ & $+0.2(2)$ \\
\hline & $d_{2}$ (av) & $-0.07(6)$ & -- & $-0.7(4)$ & $-0.16(2)$ & $+0.39(4)$ & $-0.75(0)$ & $-0.5(3)$ & $-0.0(1)$ \\
\hline & $d_{3}(a v)$ & $-0.1(2)$ & -- & $-0.62(1)$ & $+0.3(5)$ & $-0.39(4)$ & $+0.18(0)$ & $+0.0(4)$ & $-0.04(3)$ \\
\hline \multirow{10}{*}{ Doublet } & $\alpha(a v)$ & 91.7 & 91.7 & 91.9 & 91.6 & $\begin{array}{l}81.1 \\
(89.7)^{*}\end{array}$ & 89.8 & 90.6 & 90.5 \\
\hline & $\beta$ (av) & 91.7 & 92 & 92 & 91.6 & $\begin{array}{l}103.5 \\
(94.5)^{*}\end{array}$ & 94.6 & 93.5 & 93.9 \\
\hline & $d_{1}(a v)$ & 0 & +0.01 & +0.88 & +0.01 & $\begin{array}{l}0.0 \\
(+0.02)\end{array}$ & 0.0 & 0.0 & 0.0 \\
\hline & $d_{2}(a v)$ & 0 & +0.01 & -0.41 & +0.01 & $\begin{array}{l}-1.23 \\
(+0.51)^{*}\end{array}$ & +0.62 & +0.58 & +0.63 \\
\hline & $d_{3}$ (av) & 0 & +0.01 & -0.37 & -0.01 & $\begin{array}{l}+1.23 \\
(-0.70)^{\star}\end{array}$ & -0.62 & 0.60 & -0.65 \\
\hline & $\alpha(a v)$ & 94 & 90.3 & 92.7 & 93.8 & $\begin{array}{l}85.2 \\
(91.3)^{*}\end{array}$ & 90.8 & 91.9 & 91.9 \\
\hline & $\beta(a v)$ & 94 & 97 & 95 & 93.9 & $\begin{array}{l}104 \\
(97.4)^{*}\end{array}$ & 97.2 & 96.2 & 96.3 \\
\hline & $d_{1}(a v)$ & +0.02 & +0.02 & +1.30 & +0.01 & $\begin{array}{l}+0.46 \\
(+0.21)^{*}\end{array}$ & +0.31 & +0.29 & +0.38 \\
\hline & $d_{2}(a v)$ & +0.01 & -0.08 & -0.36 & +0.04 & $\begin{array}{l}-1.01 \\
(+0.58)^{*}\end{array}$ & +0.33 & +0.30 & +0.24 \\
\hline & $d_{3}(a v)$ & +0.01 & +0.09 & -0.40 & +0.04 & $\begin{array}{l}+1.13 \\
(-0.61)^{\star}\end{array}$ & -0.80 & -0.64 & -0.73 \\
\hline
\end{tabular}


The ligands in $\mathbf{C 1}$ are fully planar $(<0.07 \AA$ deviation), while those in $\mathbf{C 8}$ deviate slightly from ideal planarity ( $\mathrm{d}_{1}$ is only $+0.2 \AA$ ). Ligands in $\mathbf{C 3}$ show the largest deviation, which likely originates from the steric repulsion of hydrogens from central and distal 3-pyridyl positions. As a result, the central pyridyl ring is displaced upwards $\left(\mathrm{d}_{1}=+1.14 \AA\right)$ and the distal ones are displaced downwards $\left(\mathrm{d}_{2}=-0.70 \AA, \mathrm{d}_{3}=-0.62 \AA\right)$. In contrast, ligands in C4, C5, C6 and C7 have a distorted shape, with a $\mathrm{d}_{2}$ value as high as $0.75 \AA$ in $\mathbf{C 6}$. It seems that planarity is obtained when the three pyridyl moieties of the ligand are identical, while significant distortions occur when they differ in their substituents.

Table 2 reveals that the bond lengths between the cobalt ion and the central nitrogen $\left(\mathrm{Co}-\mathrm{N}_{\text {cent }}\right)$ are $0.09-0.25 \AA$ shorter than the distance between the cobalt ion and the distal nitrogen $(\mathrm{Co}-$ $\mathrm{N}_{\text {dist }}$ ). Surprisingly, the Co- $\mathrm{N}_{\text {cent }}$ distance in complex $\mathbf{C} 4$ is significantly shorter (1.88 $\AA$ ) than the corresponding Co- $\mathrm{N}_{\text {cent }}$ distances in the other complexes that vary in the range of $2.02-2.06 \AA$. The Co- $\mathrm{N}_{\text {dist }}$ bond lengths in that complex $(2.06 \AA)$ are also significantly shorter than the $\mathrm{Co}-$ $\mathrm{N}_{\text {dist }}$ distances in the other complexes $(2.15-2.27 \AA)$. Since the redox state of these systems is the same, it is likely that the uniqueness of $\mathbf{C 4}$ is due to adoption of a different spin state (see below). 
Table 2. Averaged bond lengths of Co-central or distal nitrogen in the crystal structures and the corresponding computed bond lengths (M06-L/6-311+G(d,p) level of theory, $0 \mathrm{~K}$ ) for both lowspin doublet and high-spin quartet spin states of complexes $\mathbf{C 1}-\mathbf{C 8}$. Values in bold are the computed Co-central nitrogen distances in agreement with the measured ones.

\begin{tabular}{|c|c|c|c|c|c|c|}
\hline & \multirow{2}{*}{\multicolumn{2}{|c|}{$\begin{array}{r}\text { Experimental } \\
\text { (standard deviation) }\end{array}$}} & \multicolumn{4}{|c|}{ DFT } \\
\hline & & & \multicolumn{2}{|c|}{ Doublet } & \multicolumn{2}{|c|}{ Quartet } \\
\hline & $\begin{array}{l}\mathrm{Co}-\mathrm{N}_{\text {cent }} \\
\text { (av) }\end{array}$ & $\begin{array}{l}\mathrm{Co}-\mathrm{N}_{\text {dist }} \\
\text { (av) }\end{array}$ & $\begin{array}{l}\mathrm{Co}-\mathrm{N}_{\text {cent }} \\
\text { (av) }\end{array}$ & $\begin{array}{l}\mathrm{Co}-\mathrm{N}_{\text {dist }} \\
\text { (av) }\end{array}$ & $\begin{array}{l}\mathrm{Co}-\mathrm{N}_{\text {cent }} \\
\text { (av) }\end{array}$ & $\begin{array}{l}\mathrm{Co}-\mathrm{N}_{\text {dist }} \\
(\mathrm{av})\end{array}$ \\
\hline C1 (100 K) & $2.05(3)$ & $2.17(2)$ & 1.898 & 2.109 & 2.089 & 2.185 \\
\hline C2 & -- & -- & 1.901 & 2.111 & 2.068 & 2.187 \\
\hline C3 (100 K) & $2.06(1)$ & $2.15(1)$ & 1.925 & 2.091 & 2.101 & 2.167 \\
\hline C4 (100 K) & $1.88(3)$ & $2.06(6)$ & 1.898 & 2.105 & 2.090 & 2.179 \\
\hline C5 $(200 \mathrm{~K})$ & $2.04(1)$ & $2.272(1)$ & 1.899 & 2.187 & 2.081 & 2.262 \\
\hline C6 $(200 \mathrm{~K})$ & $2.02(0)$ & $2.27(8)$ & 1.905 & 2.199 & 2.058 & 2.280 \\
\hline C7 (200 K) & $2.046(5)$ & $2.22(2)$ & 1.904 & 2.182 & 2.090 & 2.248 \\
\hline C8 (200 K) & $2.043(3)$ & $2.23(3)$ & 1.906 & 2.185 & 2.073 & 2.257 \\
\hline
\end{tabular}

The steric bulk of the ligands was measured using the $\mathrm{V}_{\mathrm{Bur}}(\%$ buried volume) parameter defined as the fraction of the total volume of a sphere, centered on the metal, occupied by the ligand, using the crystallographic data (Figure S58, see SI for details). ${ }^{17}$ For the calculations, the sphere radius was chosen as the distance between the cobalt center and the centroid of the two carbon atoms adjacent to the central $\mathrm{N}$ atom. That distance in $\mathbf{C 1}$ is $2.7 \AA$ and was used as a reference. The radius $\mathrm{R}$ and the mesh spacing were fixed to $3.5 \AA$ and $0.05 \AA$, respectively. Consequently, the ligands $\mathbf{L 1}$ - L8 could be classified in two classes in terms of steric hindrance (Table S3): L1 - L4 define the first class, occupying a low buried volume between $15.5-19.0$ 
$\%$, while L5 - L8 define a second class, with a larger buried volume of $24.5-26.5 \%$. Such significant differences are attributed to the presence of a methyl- or aryl-type carbon on the 2position of the distal pyridyl ring.

Cyclic voltammetry. In order to investigate the influence of the terpyridine substituents on the redox properties of the complexes, cyclic voltammograms (CVs) of complexes $\mathbf{C 1}-\mathbf{C 8}$ were recorded in acetonitrile solution. The data are shown in Figure 6 and in Table 3. All potentials are given with respect to Ferrocene / Ferrocenium redox potential. The first reduction wave for all complexes is reversible, while the reversibility of the second reduction is dependent on the ligand used. As the most cathodic wave was irreversible in the case of $\mathbf{C 2}$ and $\mathbf{C 4}$, the scan rate was varied from 50 to $1000 \mathrm{mV} / \mathrm{sec}$. While this had no effect on $\mathbf{C 2}, \mathbf{C 4}$ showed a reversible signal at high scan rates (above $100 \mathrm{mV} / \mathrm{sec}$ ). On the other hand, the $\mathrm{CV}$ of $\mathbf{C 2}$ in DMF at a scan rate of $1000 \mathrm{mV} / \mathrm{sec}$ displays reversible features (Figure S60). The observed irreversibility might result from a structural or chemical transformation of the system, possibly a decoordination of the ligand upon reduction. 


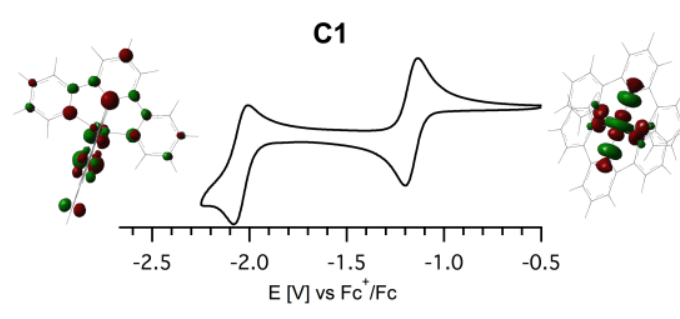

C3
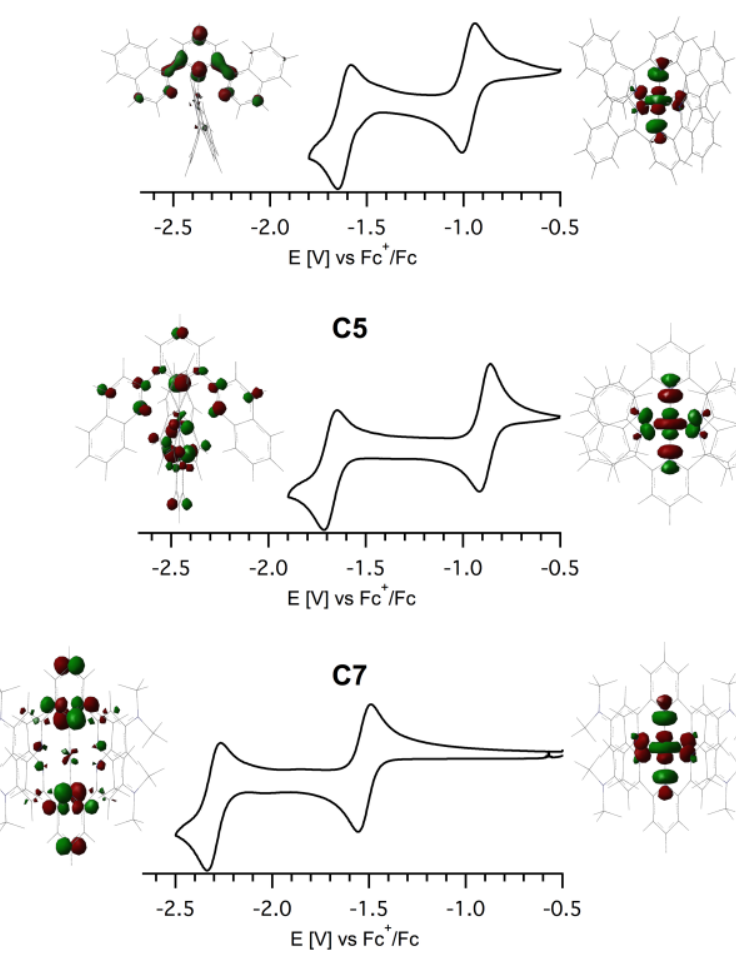

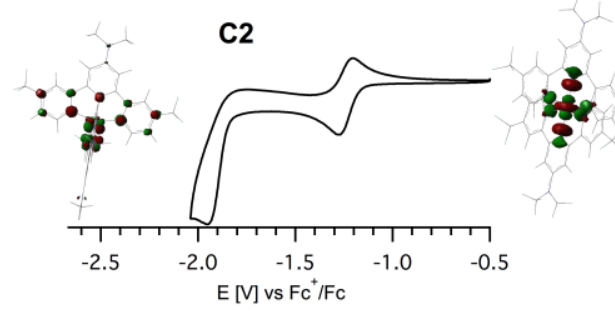

C4
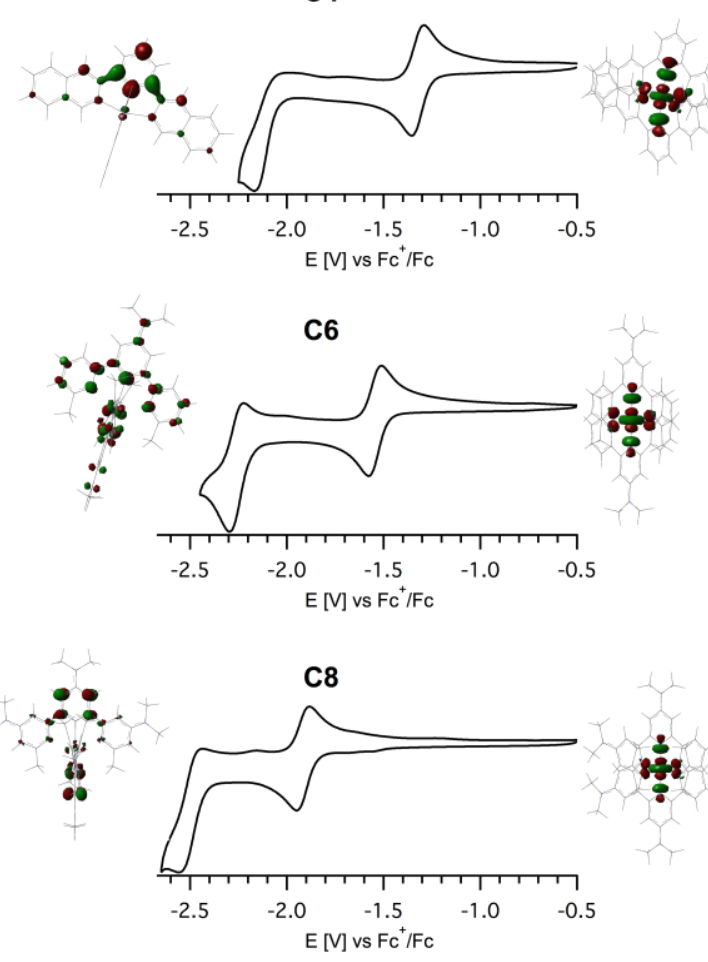

Figure 6. Cyclic voltammetry experiments of $\mathbf{C 1}-\mathbf{C 8}(1.0 \mathrm{mM})$ in acetonitrile as solvent with tetrabutylammonium perchlorate supporting electrolyte $(0.1 \mathrm{M})$. Scan rate of $50 \mathrm{mV} / \mathrm{s}$ (the two first reductions were measured). The molecular orbitals on which the electrons reside for each of the two one electron reduction events are depicted for each complex. 
Table 3. Measured reduction potential $\left(\mathrm{V} / \mathrm{Fc}^{0 /+}\right)$ of $\mathbf{C 1}-\mathbf{C 8}$ in $0.1 \mathrm{M} \mathrm{TBAClO}_{4}$ electrolyte solution in $\mathrm{CH}_{3} \mathrm{CN}$ and oxidation potential in $0.1 \mathrm{M} \mathrm{LiTFSI}$ electrolyte solution in $\mathrm{CH}_{3} \mathrm{CN}$ (see SI for details). $E^{\text {ox1 }}$ is the first oxidation of $\left[\mathrm{Co}(\text { bisterpyridyl) }]^{2+}, E^{\text {red1 }}\right.$ and $E^{\text {red2 }}$ are the first and second one-electron reduction of $[\mathrm{Co}(\text { bisterpyridyl })]^{2+}$, respectively.

\begin{tabular}{lllllllll}
\hline & C1 & C2 & C3 & C4 & C5 & C6 & C7 & C8 \\
\hline $\mathrm{E}^{\text {ox1 }}$ & -0.07 & -0.04 & -0.09 & -0.21 & +0.84 & +0.53 & +0.25 & +0.03 \\
$\mathrm{E}^{\text {red1 }}$ & -1.17 & -1.24 & -0.82 & -1.32 & -0.89 & -1.54 & -1.52 & -1.92 \\
$\mathrm{E}^{\text {red2 }}$ & -2.04 & -1.91 & -1.61 & -2.13 & -1.68 & -2.26 & -2.30 & -2.49 \\
\hline
\end{tabular}

As expected, the measured reduction potential values strongly depend on the ligand structure, spanning over a broad range of ca. 1.0 V (compare C3 and C8). The parent complex C1 was used as a reference, with $\mathrm{E}^{\mathrm{red} 1}=-1.17 \mathrm{~V}$ and $\mathrm{E}^{\mathrm{red} 2}=-2.04 \mathrm{~V}$. The $\mathrm{CV}$ of $\mathbf{C 2}$ (Figure 6) shows that two electron-withdrawing $\mathrm{CF}_{3}$ groups in the distal position compensate for the effect of one electron-donating $\mathrm{N}\left(\mathrm{CH}_{3}\right)_{2}$ group on the central position $\left(\mathbf{C} 2\right.$ : $\mathrm{E}^{\mathrm{red} 1}=-1.24 \mathrm{~V}$ and $\mathrm{E}^{\mathrm{red} 2}=-1.91$ V). Interestingly, the quinoline derivatives $\mathbf{L 3}$ and $\mathbf{L 5}$ (ortho- and para-isomers) act as electrondeficient ligands leading to anodically shifted reduction waves $\left(\mathbf{C} 3\right.$ : $\mathrm{E}^{\mathrm{red} 1}=-0.82 \mathrm{~V} ; \mathrm{E}^{\mathrm{red} 2}=-1.61$ $\mathrm{V}$; C5: $\mathrm{E}^{\text {red1 }}=-0.89 \mathrm{~V} ; \mathrm{E}^{\mathrm{red} 2}=-1.68 \mathrm{~V}$ ). In the case of complex $\mathbf{C 4}$, the measured redox potential values are found in the range of those of $\mathbf{C 1}\left(\mathbf{C} 4: \mathrm{E}^{\mathrm{red} 1}=-1.32 \mathrm{~V}\right.$; $\left.\mathrm{E}^{\mathrm{red} 2}=-2.13 \mathrm{~V}\right)$.

As far as the ligands with dimethylamino groups were concerned, two main conclusions could be drawn. First, as revealed by the similar redox potential values of $\mathbf{C 6}$ and $\mathbf{C} 7$ (C6: $\mathrm{E}^{\text {red } 1}=-1.54$ $\left.\mathrm{V} ; \mathrm{E}^{\mathrm{red} 2}=-2.26 \mathrm{~V} ; \mathbf{C} 7: \mathrm{E}^{\mathrm{red} 1}=-1.52 \mathrm{~V} ; \mathrm{E}^{\mathrm{red} 2}=-2.30 \mathrm{~V}\right)$, the effect of a single substituent on the central pyridyl moiety (C6) is equivalent to that of one on each of the distal positions (C7). This is consistent with the Co- $\mathrm{N}_{\text {cent }}$ bond length being ca. $0.2 \AA$ shorter than the $\mathrm{Co}-\mathrm{N}_{\text {dist }}$ ones, suggesting a stronger interaction of the cobalt with the central pyridyl ring. Second, introducing a 
dimethylamino group on each of the three rings generates the most electron-rich ligand $\mathbf{L 8}$, resulting in very negative potential values for $\mathbf{C 8}\left(\mathrm{E}^{\mathrm{red} 1}=-1.92 \mathrm{~V}\right.$ and $\left.\mathrm{E}^{\mathrm{red} 2}=-2.49 \mathrm{~V}\right)$. Based on these considerations, the electron donating power of the ligands could be classified as follows: $\mathbf{L 8}>\mathbf{L} 7 \approx \mathbf{L 6}>\mathbf{L 4}>\mathbf{L 1}>\mathbf{L 2}>\mathbf{L 5}>\mathbf{L 3}$. Interestingly, the very cathodic potential of $-2.30 \mathrm{~V}$ with full reversibility observed in the case of complex $\mathbf{C} 7$, combined with its very high solubility in acetonitrile, makes it a promising compound for redox flow batteries applications.

Initial attempts to measure the oxidation potential of $\mathbf{C 1}$ were performed under the conditions used for the reduction (glassy carbon electrode, $0.1 \mathrm{M} \mathrm{TBAClO}_{4}$ electrolyte in acetonitrile, Figure S62). However, the strong increase of current observed at $\approx-0.1 \mathrm{~V}$ indicated formation of a solid deposit on the electrode. Interestingly, a fully reversible wave was observed when DMF was used as a solvent (Figure S63). This could be overcome in acetonitrile by changing the electrolyte. As shown in Figure S64, lithium bistrifluoromethanesulfonimidate (LiTFSI) proved the best electrolyte and was further used to study C2 - C8 (Figure S64). Choice of the electrode material was critical, and thus, we utilized both glassy carbon and gold electrode (Figure S65). Specifically in the case of $\mathbf{C 2}$, no oxidation wave could be detected on a glassy carbon electrode, while a fully reversible oxidation was observed on a gold electrode. $\mathbf{C 1}-\mathbf{C 4}$ display a fully reversible oxidation with a peak-to-peak separation below $100 \mathrm{mV}$ (Figure S65). C5 - C8 have less resolved redox waves, with large peak-to-peak separations and/or irreversibility. Such an electrochemical behavior has been previously observed and is likely due to a slow electron selfexchange rate between the $\mathrm{Co}^{\mathrm{II}}$ and $\mathrm{Co}^{\mathrm{III}}$ centers at the electrode surface, as compared to the electron transfer rate between the electrode and the cobalt ions. ${ }^{18}$ The $\mathrm{Co}(\mathrm{III} / \mathrm{II})$ redox potentials are given in Table 3, and a comparison with other previously reported cobalt bis-terpyridyl systems is given in Figure S66 and Table S4. ${ }^{18-19}$ It shows that this class of system can span a 
broad range of potentials, more than $1 \mathrm{~V}$. As expected, in the $\mathbf{C 6}-\mathbf{C 8}$ series the Co(III/II) redox potential is shifting to more cathodic values when adding more amino substituents on the tpy ligand. Interestingly, the potential of $\mathbf{C 6}(+0.53 \mathrm{~V})$ was much more positive than that of R1 ($0.39 \mathrm{~V}$ ), a previously reported cobalt bis-terpyridyl complex with a N-pyrrolidine at the 4-central position (Figure S66 and Table S4). This is likely explained by the strong effect of the methyl groups in C6. It appears that the factors governing Co(III/II) redox potentials are rather complex and not straightforward, as strong variations can result from rather minor structural and electronic differences.

The Co(III/II) redox potentials cover a broad range of potentials, varying from $-0.21 \mathrm{~V}$ vs $\mathrm{Fc}^{+} / \mathrm{Fc}$ to $+0.84 \mathrm{~V}$ vs $\mathrm{Fc}^{+} / \mathrm{Fc}$. In the context of Dye Sensitized Solar Cells applications, ${ }^{2}$ the very high oxidation potentials observed with complexes C5, C6 and $\mathbf{C} 7(+0.84 \mathrm{~V},+0.53 \mathrm{~V}$ and +0.25 $\mathrm{V}$ vs. $\mathrm{Fc}^{+} / \mathrm{Fc}$ respectively) could be utilized with various organic photosensitizers.

Quantum Chemical Calculations. Density functional theory (DFT) calculations were performed to investigate the electronic structure of complexes $\mathbf{C 1}-\mathbf{C 8}$ and to better understand the effect of the substituents on the structure and physico-chemical properties of the complexes. The electronic and structural properties of $\left[\mathrm{Co}(\mathrm{tpy})_{2}\right]^{2+}$ referred to as $\mathbf{C 1}$ in this work, have previously been studied by Wieghardt et al. ${ }^{20}$ and Hauser et al. ${ }^{21}$

All systems contained $\mathrm{Co}$ (II) ions in a $\mathrm{d}^{7}$ electronic configuration, thus potentially allowing the existence of two different spin states, $\mathrm{a}^{2} \mathrm{E}$ low-spin doublet and a ${ }^{4} \mathrm{~T}$ high-spin quartet state. Our calculations show that for all complexes, the quartet states are energetically more favorable (within $6 \mathrm{kcal} \mathrm{mol}^{-1}$ for $\mathbf{C 1}$ - C5 and as high as 9.4, 9.5, $10.7 \mathrm{kcal} \mathrm{mol}^{-1}$ for the three dimethylamino-containing systems $\mathbf{C 6}, \mathbf{C} 7$ and $\mathbf{C 8}$, respectively) (Table S5). The optimized 
geometries are in very good agreement with the experimental X-ray data (Table 1 and Table 2), with the $\mathrm{Co}-\mathrm{N}$ bond lengths within $0.04 \AA$ of the corresponding values in the crystal structure, and the angles within $2^{\circ}$. For both doublet and quartet spin states the $\mathrm{Co}-\mathrm{N}_{\text {cent }}$ bond lengths are systematically shorter by $\sim 0.2 \AA$ as compared to the Co- $\mathrm{N}_{\text {dist }}$ ones, which is in line with our experimental findings. Moreover, the $\mathrm{Co}-\mathrm{N}_{\text {cent }}$ bond lengths vary in the narrow range of $1.90-$ $1.93 \AA$ for the low-spin states, while for the high-spin states these distances are systematically longer by $0.15-0.19 \AA$, varying in the range of $2.06-2.10 \AA$. The Co- $\mathrm{N}_{\text {dist }}$ bond lengths vary slightly in the range of $2.09-2.20 \AA$ and $2.17-2.28 \AA$ for the low and high-spin states, respectively. Hence, the Co- $\mathrm{N}_{\text {cent }}$ bond length can be used as a probe for the spin state of the complex, which is in line with having six-coordinate high- and low-spin Co ${ }^{\mathrm{II}}\left(\mathrm{t}_{2 \mathrm{~g}}{ }^{6} \mathrm{eg}_{\mathrm{g}}{ }^{1}\right.$ and $\left.\mathrm{t}_{2 \mathrm{~g}}{ }^{5} \mathrm{eg}^{2}\right)$ in an octahedral ligand field. In the low-spin complexes, the Jahn-Teller distortion will cause significant tetragonal compression, manifested in elongation of the equatorial metal-ligand (Co$\mathrm{N}_{\text {dist }}$ ) bonds, which coupled with the rigid structure of the tpy ligands will cause the shortening of the $\mathrm{Co}-\mathrm{N}_{\mathrm{cent}}$ bond lengths. Our findings are in agreement with previous results on Cobalt polypyridyl-based complexes $\left(\left[\mathrm{Co}(\mathrm{tpy})_{2}\right]^{2+},\left[\mathrm{Co}\left({ }^{(\mathrm{bpy}}\right)_{3}\right]^{2+}\right.$, and $\left.\left[\mathrm{Co}(\mathrm{phen})_{3}\right]^{2+}\right),{ }^{20}$ as well as $\left(\left[\mathrm{Co}(\mathrm{tpy})_{2}\right]^{2+}\right.$ and $\left.\left[\mathrm{Co}(\mathrm{bpy})_{3}\right]^{2+}\right) .{ }^{21} \mathrm{~A}$ closer inspection of Table 2 thus reveals that best agreement with our crystal structures is obtained when complexes $\mathbf{C 1}-\mathbf{C 3}$ and $\mathbf{C 5}-\mathbf{C 8}$ are in their highspin quartet state, while only $\mathbf{C} \mathbf{4}$ is best described as a low-spin doublet. One should note that, as demonstrated for $\mathbf{C 1}$, the spin state is strongly influenced by the environment of the complex, depending on parameters such as the nature of the counter-ion, the nature and number of solvent molecules in crystalline media or solution, or the temperature. ${ }^{22}$ Table 1 shows that the computed acute $\alpha$ and obtuse $\beta \mathrm{N}_{\text {dist }}-\mathrm{Co}-\mathrm{N}_{\text {dist }}$ angles are also in excellent agreement with the experimental values, except for complex C5. The two L5 ligands in complex C5 deviate significantly from 
orthogonality, due to favorable $\pi-\pi$ stacking between the para-quinoline moieties (see Figure S75). Test calculations with different DFT functionals, such as B3LYP-D3, B97D and M06 predicted virtually the same geometry. A closer inspection of the $\mathbf{C 5}$ crystal structure revealed that such dispersive interactions are prevented by the existence of four aromatic rings: two toluene solvent molecules and two central pyridyl units from the neighboring $\mathbf{C 5}$ complexes in the unit cell. We have thus performed an optimization of C5 with four toluene molecules between the quinoline ligands, and indeed the perpendicular arrangement of the $\mathbf{L 5}$ ligands is maintained, in a good agreement with the experimental structure (see Table 1).

The DFT computed descriptors also indicate that the ligands in all complexes deviate significantly from planarity, except for both spin states of $\mathbf{C 2}$ and $\mathbf{C 4}$. In $\mathbf{C 5}$ the para-quinoline units are $1.0-1.2 \AA$ out of the plane (exp. $\mathrm{d}_{2,3}$ is $\pm 0.4 \AA$ ), which gets corrected to largest deviation of $\sim 0.7 \AA$ when four solvent molecules are explicitly included in the geometry optimization of the complex. Even larger deviation from planarity of the ligands is calculated for the ortho-quinoline-based complex $\mathbf{C} \mathbf{3}\left(\mathrm{d}_{1}=1.30 \AA\right.$ vs. the corresponding experimental value of $1.14 \AA$ ), owning it to the large steric repulsion of hydrogens from the central and distal pyridyl rings within each ligand $\mathbf{L 3}$. Introducing two electron-withdrawing $\mathrm{CF}_{3}$ groups on the distal pyridyl units along with a single electron-donating $\mathrm{N}\left(\mathrm{CH}_{3}\right)_{2}$ group on the central ring in $\mathbf{C 2}$ complex has virtually no effect on the geometry and the structure remains essentially identical to C1. For the terpyridines containing dimethylamino groups, C6 - C8, our calculations consistently find distortion of planarity for their doublet spin states by $\sim 0.6 \AA$ in terms of $\mathrm{d}_{2}$ and $d_{3}$ descriptors, while $d_{1}=0$. The high-spin state structures are more planar (displacements of $\sim$ $0.4 \AA$ max), with largest deviations $\left(\mathrm{d}_{3} \sim 0.75 \AA\right.$ ) found for $\mathbf{C 6}$ and $\mathbf{C 8}$, which is caused by the two $\mathrm{N}\left(\mathrm{CH}_{3}\right)_{2}$ groups on the distal rings. 
The spin density plots of complexes C1 - C8 (Figures S67 - S74) reveal the dominant contribution of $\mathrm{Co}(\mathrm{II})$, with $\rho=0.97-0.99$ in the low-spin doublet state and $\rho=2.73-2.87$ in the high-spin quartet state and very little density on the pyridyl N atoms. Figures S67 - S74 show the frontier molecular orbitals of complexes C1 - C8. The low-spin doublet states are characterized by a HOMO that is a pure Co $3 \mathrm{~d}$ orbital, except in $\mathbf{C 2}$ and $\mathbf{C 6}$ where the $\mathrm{N}\left(\mathrm{CH}_{3}\right)_{2}$ groups at the central ring introduce an axial symmetry and the HOMO is composed of Co $3 \mathrm{~d}$ and $\mathrm{C}$ and $\mathrm{N} 2 \mathrm{p}$ orbitals in the same plane. The singly-occupied MO (SOMO) is the $\sigma^{*}$ antibonding Co- $\mathrm{N}_{\text {dist }}$ orbital composed of Co $3 \mathrm{~d} \mathrm{x}^{2}-\mathrm{y}^{2}$ and $\mathrm{N}_{\text {dist }} 2 \mathrm{p}$, while the LUMO orbital is the $\sigma^{*}$ antibonding Co- $\mathrm{N}_{\text {cent }}$ orbital composed of Co $3 \mathrm{~d} \mathrm{z}^{2}$ and $\mathrm{N}_{\text {cent }} 2 \mathrm{p}$. As far as the high-spin quartets are concerned, the HOMO orbital is either a ligand-based orbital $(\mathbf{C 1}, \mathbf{C 3}, \mathbf{C 5}, \mathbf{C 7}$ and $\mathbf{C 8})$ or the antibonding Co- $\mathrm{N}_{\text {dist }}$ orbital composed of Co $3 \mathrm{~d} \mathrm{x}^{2}-\mathrm{y}^{2}$ and N $2 \mathrm{p}$ as in C2, C4 and C6. The three unpaired electrons reside on two ligand-based orbitals and the $\mathrm{Co}-\mathrm{N}_{\text {cent }} \sigma^{*}$ antibonding orbitals of Co $3 \mathrm{~d} \mathrm{z}^{2}$, while, while the LUMO orbital is always a ligand-based one.

Thus, the main difference in the spin states in all complexes $\mathbf{C 1}-\mathbf{C 8}$ is the population of the Co $3 \mathrm{~d} \mathrm{z}^{2}$ orbital in the quartet states, decreasing the back-bonding of Co to the central pyridyl ring, thus providing an explanation of the change in the $\mathrm{Co}-\mathrm{N}_{\text {cent }}$ distance, which is elongated by $\sim 0.2 \AA$ when passing from low-spin to high-spin state.

Finally, our calculations show that the first electron reduction of complexes $\mathbf{C 1}-\mathbf{C 8}$ is always metal-based and corresponds to the reduction of $\mathrm{Co}^{\mathrm{II}}$ to $\mathrm{Co}^{\mathrm{I}}$, with an electron occupying the antibonding $\sigma^{*}$ Co- $\mathrm{N}_{\text {cent }}$ orbital (having mainly $3 \mathrm{~d} \mathrm{z}^{2}$ character). The second reduction, on the other hand, corresponds to a ligand-based event (see Figure 6). While in C1 the electron is delocalized over the entire ligands, in $\mathbf{C 2}$ it is localized on the distal rings due to the electronwithdrawing $\mathrm{CF}_{3}$ groups, while in the quinoline-based $\mathbf{C 3}$ - C5 complexes it is localized 
primarily on the central ring, involving parts of the distal quinoline rings, but not the terminal phenyl rings (C5). Similarly, in the dimethylamino-substituted complexes $\mathbf{C 7}$ and $\mathbf{C 8}$ the electron reside on the central ring, whereas in $\mathbf{C 6}$ it is delocalized on the entire $\mathbf{L 6}$ ligand. 


\section{CONCLUSIONS}

We have synthesized a series of new terpyridine ligands bearing a variety of substituting moieties using Stille cross-coupling reactions. The corresponding bis-substituted $\operatorname{Co}($ II) complexes were isolated and fully characterized. The crystal structures revealed distortions in some of these systems, especially when the terpyridine ligands were functionalized with different substituents. The DFT calculations provided insight into understanding the differences of Co-N bond lengths observed in the crystal structures, assigning them to differences in terms of spin states. In particular, the $\mathrm{Co}-\mathrm{N}_{\text {cent }}$ bond length can be used as a probe for differentiating the lowspin doublet from the high-spin quartet state. In this work, we have shown that the redox potential of the $\mathrm{Co}(\mathrm{III}) / \mathrm{Co}(\mathrm{II}), \mathrm{Co}(\mathrm{II}) / \mathrm{Co}(\mathrm{I})$ and $\mathrm{Co}(\mathrm{I}) / \mathrm{Co}(\mathrm{I})(\mathrm{tpy}) \bullet-$ couples can be easily modulated over $1 \mathrm{~V}$ by tuning the substituents on the tpy ligands, allowing to cover a broad range of applications. Study of the catalytic properties of this class of complexes is currently ongoing.

\section{EXPERIMENTAL SECTION}

General. NMR spectra were recorded on Bruker AVANCE III 300 spectrometer (Bruker BioSpin GmbH, Rheinstetten, Germany). HR-ESI-MS spectra were recorded in a positive mode on a Waters LCT Premier XE mass spectrometer equipped with an electrospray ionization source. The ionization was carried out in positive mode in the $80-1500 \mathrm{~m} / \mathrm{z}$ range. LR-ESI-MS spectra of the molecular complexes were recorded in a positive mode on a PE Sciex API 3000 mass spectrometer equipped with an electrospray ionization source. UV-vis spectra were recorded on a Cary100 UV-Vis spectrophotometer (Agilent Technologies, Santa Clara, USA). Suitable crystals of the complexes were mounted in Paratone oil and transferred into a cold 
nitrogen gas stream. Intensity data was collected with Bruker Kappa-APEX2 systems using micro-source $\mathrm{Cu}-\mathrm{K} \alpha$ or fine-focus sealed tube Mo-K $\alpha$ radiation or using an Oxford-Diffraction XCallibur S kappa geometry diffractometer (Mo-K $\alpha$ radiation, graphite monochromator, $\lambda=$ $0.71073 \AA$ ). Data collection was carried out with the Bruker APEX2 suite of programs (APEX2 diffractometer) and by CrysAlisPro Oxford-diffraction software (XCallibur diffractometer). Unit-cell parameters determination, integration and data reduction were performed with SAINT (APEX II) Alternatively, unique intensities detected on all frames using the Oxford-diffraction Red program were used to refine the values of the cell parameters (XCallibur). SADABS ${ }^{23}$ (APEX II) and the ABSPACK Oxford-diffraction programs were used for scaling and multi-scan absorption corrections. The structures were solved with WinGX and Olex2 1.2 using SHELXT$2014{ }^{24}$ package and refined by full-matrix least-squares methods with SHELXL-2014. All nonhydrogen atoms were refined anisotropically. Hydrogen atoms were placed at calculated positions and refined with a riding model. Electrochemical measurements were performed using a Bio-Logic SP300 potentiostat model (Bio-Logic, Claix, France). CVs were recorded in a glovebox to prevent oxygen. An electrochemical cell with a glassy carbon electrode as a working electrode $(\varnothing=1.0 \mathrm{~mm})$, a platinum wire as a counter electrode $(\varnothing=1 \mathrm{~mm})$ and a silver wire in silver nitrate isolated from the solution using a vycor frit $\left(10 \mathrm{mM}\right.$ in $0.1 \mathrm{M} \mathrm{TBAClO}_{4}$ solution in acetonitrile) as a reference electrode in a $3.0 \mathrm{~mL}$ solution was used to measure the CVs. A gold working electrode $(\varnothing=3.0 \mathrm{~mm})$ was also used when stated. FT-IR spectra were recorded on a IR Prestige-21 Spectrometer with Universal ATR Sampling Accessory (Shimadzu, Kyoto, Japan). Purifications with flash liquid chromatography were carried out using a Reveleris X2 system (Grace, Columbia, USA) equipped with disposable silica columns. For synthesis, the solutions 
were degassed (when mentioned) by bubbling argon in the solution for at least 20 minutes. Dry solvents (when mentioned) were obtained using a MBraun Solvent Purification System.

Computational Methods. Molecular geometries were optimized at the M06-L $\mathrm{L}^{25} / 6$ $311+\mathrm{G}(\mathrm{d}, \mathrm{p})^{26}$ level of density functional theory using the Gaussian 09 software package. ${ }^{27}$ Quasirelativistic Stuttgart/Dresden effective core potential was used on Co. ${ }^{28}$ The integral evaluation made use of the grid defined as "ultrafine" in G09. Frequency calculations on optimized geometries insured structures were minima (zero imaginary frequency) on the potential energy surface.

Synthesis of L2. In a Schlenk flask, a toluene solution $(7.0 \mathrm{~mL})$ of $\mathbf{S 3}(181 \mathrm{mg}, 0.485 \mathrm{mmol})$ and $\mathbf{S 9}$ (0.635 g, $1.45 \mathrm{mmol})$ was degassed under argon during $15 \mathrm{~min}$. The catalyst $\left[\mathrm{Pd}\left(\mathrm{PPh}_{3}\right)_{4}\right]$ (47.0 $\mathrm{mg}, 0.042 \mathrm{mmol}$ ) was added and the solution was degassed again under argon during 15 min. The solution was heated at $110^{\circ} \mathrm{C}$ for $96 \mathrm{~h}$. The solvent was removed in vacuum and the residue was purified was column chromatography (cyclohexane / ethyl acetate gradient) to yield $\mathbf{L 2}$ as a white powder (103 mg, $0.25 \mathrm{mmol}, 52 \%$ ). IR (ATR) $v_{\max }\left(\mathrm{cm}^{-1}\right): 2926(\mathrm{w}), 2854(\mathrm{w})$, 2816 (w), 1589 (w), 1541 (w), 1506 (w), 1471 (w), 1431 (w), 1413 (w), 1379 (w), 1328 (w), $1276(w), 1253(w), 1228(w), 1165(w), 1124(m), 1070(w), 1004(w), 991(w), 975(w), 920$ (w), 894 (w), 840 (m), 788 (w), $700(\mathrm{w}), 663$ (m), 607 (w) ; ${ }^{1} \mathrm{H}-\mathrm{NMR}\left(300 \mathrm{MHz}, \mathrm{CDCl}_{3}\right.$ ): 3.34 (s, 3H), $7.59(\mathrm{~d}, J=5.0 \mathrm{~Hz}, 2 \mathrm{H}), 7.91(\mathrm{~s}, 2 \mathrm{H}), 8.8-9.0(\mathrm{~m}, 2 \mathrm{H}) ;{ }^{13} \mathrm{C}-\mathrm{NMR}\left(75 \mathrm{MHz}, \mathrm{CDCl}_{3}\right)$ 40.28, 104.93, 117.67, 119.72, 124.68, 149.86 (2C), 156.00 - 157.5 (3C); HR-MS (ESI+) $\mathrm{m} / z$ calcd. for $\mathrm{C}_{19} \mathrm{H}_{15} \mathrm{~F}_{6} \mathrm{~N}_{4}^{+}: 413.1195$, found: $413.1201\left([\mathrm{M}+\mathrm{H}]^{+}\right)$. 
Synthesis of L3. In a Schlenk flask, a toluene solution (18 mL) of S5 (0.53 g, $1.3 \mathrm{mmol})$ and S10 (1-chloroisoquinoline) (1.0 g, $3.9 \mathrm{mmol}$, Fluorochem) was degassed under argon during 15 min. The catalyst $\left[\mathrm{Pd}\left(\mathrm{PPh}_{3}\right)_{4}\right](0.153 \mathrm{~g}, 0.13 \mathrm{mmol})$ was added and the solution was degassed again under argon during $15 \mathrm{~min}$. The solution was heated at $110^{\circ} \mathrm{C}$ for $96 \mathrm{~h}$. The solvent was removed in vacuum and the residue was purified was column chromatography (cyclohexane / ethyl acetate gradient). The isolated product was recrystallized in acetonitrile, and dried under vacuum to yield $\mathbf{L 3}$ as a white powder (191 mg, $0.57 \mathrm{mmol}, 44 \%$ ). IR (ATR) $v_{\max }\left(\mathrm{cm}^{-1}\right): 3043$ (w), 3007 (w), 2924 (w), 2852 (w), $1568(w), 1435(w), 1373(w), 1346(w), 1319(w), 1249(w)$, $1238(w), 1215(w), 1126(w), 1089(w), 1022(w), 952(w), 916(w), 869(w), 835(w), 819(w)$, 798 (w), 789 (w), 734 (w), 704 (w), 669 (w); ${ }^{1} \mathrm{H}-\mathrm{NMR}\left(300 \mathrm{MHz}, \mathrm{CDCl}_{3}\right): 7.51$ (t, J= $7.5 \mathrm{~Hz}$, 2H), $7.68(\mathrm{t}, J=7.5 \mathrm{~Hz}, 2 \mathrm{H}), 7.76(\mathrm{~d}, J=5.5 \mathrm{~Hz}, 2 \mathrm{H}), 7.88(\mathrm{~d}, J=7.5 \mathrm{~Hz}, 2 \mathrm{H}), 8.16(\mathrm{~s}, 3 \mathrm{H})$, $8.68(\mathrm{~d}, J=5.5 \mathrm{~Hz}, 2 \mathrm{H}), 8.75(\mathrm{~d}, J=7.5 \mathrm{~Hz}, 2 \mathrm{H}) ;{ }^{13} \mathrm{C}-\mathrm{NMR}\left(75 \mathrm{MHz}, \mathrm{CDCl}_{3}\right): 121.40,124.81$, 126.84, 126.91, 127.62, 128.13, 130.13, 137.19, 137.89, 141.81, 157.32, 157.48; HR-MS (ESI+) $m / z$ calcd. for $\mathrm{C}_{23} \mathrm{H}_{16} \mathrm{~N}_{3}{ }^{+}$: 334.1339 , found: $334.1344\left([\mathrm{M}+\mathrm{H}]^{+}\right)$.

Synthesis of L4. In a Schlenk flask, a toluene solution (18 mL) of S5 (0.53 g, $1.3 \mathrm{mmol})$ and S11 (3-chloroisoquinoline) (1.0 g, $3.9 \mathrm{mmol}$, Fluorochem) was degassed under argon during 15 min. The catalyst $\left[\mathrm{Pd}\left(\mathrm{PPh}_{3}\right)_{4}\right](0.153 \mathrm{~g}, 0.13 \mathrm{mmol})$ was added and the solution was degassed again under argon during $15 \mathrm{~min}$. The solution was heated at $110^{\circ} \mathrm{C}$ for $96 \mathrm{~h}$. The solvent was removed in vacuo and the residue was purified was column chromatography (cyclohexane / ethyl acetate gradient). The isolated product was recrystallized in acetonitrile, and dried under vacuum to yield L4 as a white powder (170 mg, $0.51 \mathrm{mmol}, 39 \%$ ). IR (ATR) $v_{\max }\left(\mathrm{cm}^{-1}\right): 3057(\mathrm{w}), 3024$ (w), $2980(w), 2964(w), 2926(w), 2854(w), 1625(w), 1581(w), 1562(w), 1492(w), 1463(w)$, 
$1438(w), 1427(w), 1386(w), 1342(w), 1267(w), 1255(w), 1236(w), 1192(w), 1136(w), 945$ (w), $900(\mathrm{w}), 885(\mathrm{w}), 850(\mathrm{w}), 817$ (m), $734(\mathrm{~m}), 675$ (w); ${ }^{1} \mathrm{H}-\mathrm{NMR}\left(300 \mathrm{MHz}, \mathrm{CDCl}_{3}\right): 7.64$ (t, $J=7.5 \mathrm{~Hz}, 2 \mathrm{H}), 7.76(\mathrm{t}, J=7.5 \mathrm{~Hz}, 2 \mathrm{H}), 8.06(\mathrm{~m}, 5 \mathrm{H}), 8.56(\mathrm{~d}, J=7.5 \mathrm{~Hz}, 2 \mathrm{H}), 9.06(\mathrm{~s}, 2 \mathrm{H})$, 9.37 (s, 2H); ${ }^{13} \mathrm{C}-\mathrm{NMR}\left(75 \mathrm{MHz}, \mathrm{CDCl}_{3}\right): 117.78,120.93,127.57,127.65,127.75,128.81$, 130.55, 136.69, 137.98, 150.19, 152.08, 155.95; HR-MS (ESI+) $m / z$ calcd. for $\mathrm{C}_{23} \mathrm{H}_{16} \mathrm{~N}_{3}{ }^{+}$: 334.1339, found: $334.1344\left([\mathrm{M}+\mathrm{H}]^{+}\right)$.

Synthesis of L5. In a Schlenk flask, a toluene solution (12 mL) of S5 (0.36 g, $0.89 \mathrm{mmol})$ and S7 (2-iodoquinoline) (0.60 g, $2.67 \mathrm{mmol}$, Fluorochem) was degassed under argon during $15 \mathrm{~min}$. The catalyst $\left[\mathrm{Pd}\left(\mathrm{PPh}_{3}\right)_{4}\right](0.104 \mathrm{~g}, 0.09 \mathrm{mmol})$ was added and the solution was degassed again under argon during 15 min. The solution was heated at $110{ }^{\circ} \mathrm{C}$ for $96 \mathrm{~h}$. The solvent was removed in vacuum and the residue was purified was column chromatography (cyclohexane / ethyl acetate gradient) to yield $\mathbf{L 5}$ as a yellowish powder (282 mg, $0.84 \mathrm{mmol}, 94 \%$ ); IR (ATR) $v_{\max }\left(\mathrm{cm}^{-1}\right): 3051(w), 2995(w), 2895(w), 2798(w), 2763(w), 2742(w), 2655(w), 1616(w)$ $1595(\mathrm{~m}), 1556(\mathrm{~m}), 1502(\mathrm{~m}), 1433$ (m), $1423(\mathrm{~m}), 1321(\mathrm{w}), 1305(\mathrm{w}), 1247(\mathrm{w}), 1236(\mathrm{w})$, $1122(\mathrm{~m}), 1084(\mathrm{~m}), 1060(\mathrm{w}), 1014(\mathrm{w}), 993(\mathrm{w}), 956(\mathrm{w}), 941(\mathrm{w}), 831(\mathrm{~m}), 815(\mathrm{~m}), 785(\mathrm{~m})$, $733(\mathrm{~m}), 771$ (w). ${ }^{1} \mathrm{H}-\mathrm{NMR}\left(300 \mathrm{MHz}, \mathrm{CDCl}_{3}\right): 7.85$ (t, J = 7.5 Hz, 2H), 7.77 (t, J= $\left.7.5 \mathrm{~Hz}, 2 \mathrm{H}\right)$, $7.89(\mathrm{~d}, J=8.5 \mathrm{~Hz}, 2 \mathrm{H}), 8.08(\mathrm{t}, J=7.5 \mathrm{~Hz}, 1 \mathrm{H}), 7.22(\mathrm{~d}, J=8.5 \mathrm{~Hz}, 2 \mathrm{H}), 8.35(\mathrm{~d}, J=8.5 \mathrm{~Hz}$, 2H), $7.78(\mathrm{~d}, J=7.5 \mathrm{~Hz}, 2 \mathrm{H}), 8.85(\mathrm{~d}, J=8.5 \mathrm{~Hz}, 2 \mathrm{H})$; HR-MS (ESI+) $m / z$ calcd. for $\mathrm{C}_{23} \mathrm{H}_{16} \mathrm{~N}_{3}{ }^{+}$: 334.1339, found: $334.1344\left([\mathrm{M}+\mathrm{H}]^{+}\right)$.

Synthesis of L6. In a Schlenk flask, a toluene solution $(2.5 \mathrm{~mL})$ of $\mathbf{S 3}(65.0 \mathrm{mg}, 0.175 \mathrm{mmol})$ and S12 (2-methyl-6-(tributylstannyl)pyridine) (0.20 g, $0.523 \mathrm{mmol}$, Sigma-Aldrich) was 
degassed under argon during $15 \mathrm{~min}$. The catalyst $\left[\mathrm{Pd}\left(\mathrm{PPh}_{3}\right)_{4}\right](17.0 \mathrm{mg}, 0.015 \mathrm{mmol})$ was added and the solution was degassed again under argon during $15 \mathrm{~min}$. The solution was heated at 110 ${ }^{\circ} \mathrm{C}$ for $96 \mathrm{~h}$. The solvent was removed in vacuo and the residue was purified was column chromatography (cyclohexane / ethyl acetate gradient) to yield $\mathbf{L 6}$ as a white powder (20 mg, $0.065 \mathrm{mmol}, 37 \%$ ). IR (ATR) $v_{\max }\left(\mathrm{cm}^{-1}\right)$ : $2985(\mathrm{w}), 2922(\mathrm{w}), 2885(\mathrm{w}), 2802(\mathrm{w}), 1608(\mathrm{w})$, $1570(w), 1541(w), 1506(w), 1423(w), 1411(w), 1226(w), 1141(w), 1082(w), 983(w), 852$ (w), 800 (w), 744 (w), 698 (w), 661 (w), 638 (w); ${ }^{1} \mathrm{H}-\mathrm{NMR}$ (300 MHz, CDCl 3 ): 7.14 (d, $J=7.5$ $\mathrm{Hz}, 2 \mathrm{H}), 7.71(\mathrm{t}, J=7.5 \mathrm{~Hz}, 2 \mathrm{H}), 7.76(\mathrm{~s}, 2 \mathrm{H}), 8.39$ (d, $J=7.5 \mathrm{~Hz}, 2 \mathrm{H}) ;{ }^{13} \mathrm{C}-\mathrm{NMR}(75 \mathrm{MHz}$, $\left.\mathrm{CDCl}_{3}\right): 24.70,39.64,103.72,118.49,122.95,136.68,155.78,156.42,157.52$ (2C); HR-MS (ESI+) $m / z$ calcd. for $\mathrm{C}_{19} \mathrm{H}_{21} \mathrm{~N}_{4}{ }^{+}: 305.1761$, found: $305.1766\left([\mathrm{M}+\mathrm{H}]^{+}\right)$.

General procedure for the synthesis of molecular complexes (except C5). To a solution of anhydrous $\mathrm{CoCl}_{2}$ (1.0 equiv., Sigma-Aldrich) in degassed methanol $\left(1.0 \mathrm{~mL} / 15 \mu \mathrm{mol} \mathrm{CoCl}_{2}\right)$ was added a powder of the terpyridyl ligand (2.0 equiv.). The solution was refluxed for 3 hours under argon, and cooled to room temperature. The complex was precipitated after addition of a concentrated aqueous solution of ammonium hexafluorophosphate (8.0 equiv., Sigma-Aldrich), and the product was collected by filtration. The product was thoroughly washed with each time $20 \mathrm{~mL}$ of water (milliQ), toluene, and $\mathrm{Et}_{2} \mathrm{O}$. The obtained powder was dissolved in a minimum amount of acetone, and toluene was added dropwise until the complex precipitated. The precipitate was collected and dried under vacuum to provide $\mathbf{C 1}-\mathbf{C 8}$.

Synthesis of C5. To a solution of anhydrous $\mathrm{CoCl}_{2}$ (1.0 equiv., Sigma-Aldrich) in degassed methanol $\left(1.0 \mathrm{~mL} / 7.5 \mu \mathrm{mol} \mathrm{CoCl}_{2}\right)$ was added a powder of the terpyridyl ligand (2.0 equiv.). 
The solution was refluxed for 3 hours under argon, and cooled to room temperature. A concentrated solution of ammonium hexafluorophosphate (8.0 equiv., Sigma-Aldrich) in methanol was added, and the solvent was removed with rotary evaporator. The product was thoroughly washed with each time $20 \mathrm{~mL}$ of water (milliQ), toluene, and $\mathrm{Et}_{2} \mathrm{O}$. The obtained powder was dissolved in a minimum amount of acetone, and toluene was added dropwise until the complex precipitated. The precipitate was collected and dried under vacuum to provide $\mathbf{C 5}$.

C1: Isolated yield: $93 \%$; ${ }^{1} \mathrm{H}$ NMR (300 MHz, $\mathrm{CD}_{3} \mathrm{CN}$ ): 98.88, 56.77, 48.24, 33.97, 21.25, 8.39; IR (ATR) $v_{\max }\left(\mathrm{cm}^{-1}\right): 3130(\mathrm{w}), 3095(\mathrm{w}), 2972(\mathrm{w}), 2900(\mathrm{w}), 2885(\mathrm{w}), 1600(\mathrm{w}), 1577$ (w), $1473($ w), $1452(w), 1436(w), 1323(w), 1244(w), 1193(w), 1051(w), 1029(w), 1014(w)$, 902 (w), 879 (w), 837 (s), 819 (s), 767 (s), 740 (w), 729 (w), 690 (w); Anal. Calcd for $\mathrm{C}_{30} \mathrm{H}_{22} \mathrm{CoF}_{12} \mathrm{~N}_{6} \mathrm{P}_{2}: \mathrm{C}, 44.19 ; \mathrm{H}, 2.72 ; \mathrm{N}, 10.31$. Found: $\mathrm{C}, 44.33 ; \mathrm{H}, 2.66 ; \mathrm{N}, 10.28$. LRMS $\left(\mathrm{ESI}^{+}\right), m / z: 670.3\left(\left[\mathrm{M}-\mathrm{PF}_{6}\right]^{+}\right), 262.6\left(\left[\mathrm{M}-2 \mathrm{PF}_{6}\right]^{2+}\right)$.

C2: Isolated yield: $82 \%$; ${ }^{1} \mathrm{H}$ NMR (300 MHz, $\left.\mathrm{CD}_{3} \mathrm{CN}\right)$ : 99.66, 83.20, 68.40, 25.24, 23.75; IR (ATR) $v_{\max }\left(\mathrm{cm}^{-1}\right): 2987(w), 2972(w), 2891(w), 1616(w), 1533(w), 1506(w), 1417(w), 1330$ (m), $1288(w), 1265(w), 1230(w), 1178(w), 1165(w), 1138(w), 1089(w), 1029(w), 900(w)$, 823 (s), 734 (w), 680 (m), 665 (w); Anal. Calcd for $\mathrm{C}_{41} \mathrm{H}_{34} \mathrm{CoF}_{24} \mathrm{~N}_{8} \mathrm{OP}_{2}\left(\mathbf{C} 2 \cdot \mathrm{CH}_{3} \mathrm{COCH}_{3}\right)$ : C, 39.98; H, 2.78; N, 9.10. Found: C, 40.31; H, 2.63; N, 8.95. LRMS (ESI $\left.{ }^{+}\right), m / z: 1028.4([\mathrm{M}-$ $\left.\left.\mathrm{PF}_{6}\right]^{+}\right), 441.9\left(\left[\mathrm{M}-2 \mathrm{PF}_{6}\right]^{2+}\right)$.

C3: Isolated yield: $77 \%$; ${ }^{1} \mathrm{H}$ NMR (300 MHz, $\mathrm{CD}_{3} \mathrm{CN}$ ): 105.71, 67.45, 40.06, 15.79, 13.88, 9.61, 6.80, 2.09; IR (ATR) $v_{\max }\left(\mathrm{cm}^{-1}\right): 3082(\mathrm{w}), 2972(\mathrm{w}), 2895(\mathrm{w}), 1705(\mathrm{w}), 1622(\mathrm{w}), 1585$ (w), $1573(w), 1552(w), 1471(w), 1456(w), 1386(w), 1354(w), 1311(w), 1271(w), 1222(w)$, $1186(w), 1020$ (w), 875 (w), 833 (s), 821 (s), 740 (w), 667 (w); Anal. Calcd for 
$\mathrm{C}_{53} \mathrm{H}_{38} \mathrm{CoF}_{12} \mathrm{~N}_{6} \mathrm{P}_{2}(\mathbf{C} 3 \cdot P h M e):$ C, 57.46; H, 3.46; N, 7.59. Found: C, 57.36; H, 3.35; N, 7.25. LRMS (ESI $\left.{ }^{+}\right), m / z: 870.6\left(\left[\mathrm{M}-\mathrm{PF}_{6}\right]^{+}\right), 362.7\left(\left[\mathrm{M}-2 \mathrm{PF}_{6}\right]^{2+}\right)$.

C4: Isolated yield: $71 \%$; ${ }^{1} \mathrm{H}-\mathrm{NMR}\left(300 \mathrm{MHz}, \mathrm{CD}_{3} \mathrm{CN}\right)$ : 111.46, 55.40, 46.74, 21.27, 10.15, 9.27, 7.96, 7.89, 6.08; IR (ATR) $v_{\max }\left(\mathrm{cm}^{-1}\right): 3093(\mathrm{w}), 2972(\mathrm{w}), 2885(\mathrm{w}), 1625(\mathrm{w}), 1602(\mathrm{w})$, $1568(w), 1505(w), 1489(w), 1446(w), 1390(w), 1298(w), 1269(w), 1174(w), 968(w), 831$ (s), 810 (s), 758 (w), $736(w), 678(w)$; Anal. Calcd for $\mathrm{C}_{53} \mathrm{H}_{38} \mathrm{CoF}_{12} \mathrm{~N}_{6} \mathrm{P}_{2}(\mathbf{C} 4 \cdot \mathrm{PhMe})$ : C, 57.46; H, 3.46; N, 7.59. Found: 57.24; H, 3.36; N, 7.29. LRMS (ESI $\left.{ }^{+}\right), m / z: 870.7$ ([M-PF6] $\left.]^{+}\right), 362.7$ $\left(\left[\mathrm{M}-2 \mathrm{PF}_{6}\right]^{2+}\right)$.

C5: Isolated yield: $90 \%$; ${ }^{1} \mathrm{H}-\mathrm{NMR}\left(300 \mathrm{MHz}, \mathrm{CD}_{3} \mathrm{CN}\right.$ ): 98.64, 72.23, 27.88, 24.14, 14.77, 4.95, 3.75, 2.33; IR (ATR) $v_{\max }\left(\mathrm{cm}^{-1}\right): 3093(\mathrm{w}), 2972(\mathrm{w}), 2893(\mathrm{w}), 1593(\mathrm{w}), 1516(\mathrm{w}), 1485$ (w), 1435 (w), 1379 (w), 1342 (w), $1271($ w), 1220 (w), 1195 (w), 1148 (w), 1101 (w), 1083 (w), 1029 (w), 877 (w), 825 (s), 806 (s), 779 (m), 761 (m), 738 (m), 686 (w); Calcd for $\mathrm{C}_{53} \mathrm{H}_{38} \mathrm{CoF}_{12} \mathrm{~N}_{6} \mathrm{P}_{2}(\mathbf{C} 5 \cdot \mathrm{PhMe} \mathrm{C}, 57.46 ; \mathrm{H}, 3.46 ; \mathrm{N}, 7.59$. Found: C, 57.18; H, 3.43; N, 7.27. LRMS $\left(\mathrm{ESI}^{+}\right), m / z: 870.7\left(\left[\mathrm{M}-\mathrm{PF}_{6}\right]^{+}\right), 362.8\left(\left[\mathrm{M}-2 \mathrm{PF}_{6}\right]^{2+}\right)$.

C6: Isolated yield: $86 \%$; ${ }^{1} \mathrm{H}-\mathrm{NMR}\left(300 \mathrm{MHz}, \mathrm{CD}_{3} \mathrm{CN}\right)$ : 113.79, 77.10, 35.85, 20.17, -0.95, 11.67; IR (ATR) $v_{\max }\left(\mathrm{cm}^{-1}\right): 2972(\mathrm{w}), 2900(\mathrm{w}), 1618$ (w), 1604 (w), $1573(\mathrm{w}), 1533(\mathrm{w}), 1456$ (w), $1438($ (w), 1379 (w), 1307 (w), 1251 (w), 1166 (w), $1114($ w), $1070($ w), 1047 (w), 997 (w), $906(w), 873(w), 831(\mathrm{~s}), 800(\mathrm{~m}), 742(\mathrm{w}), 651$ (w); Anal. Calcd for $\mathrm{C}_{41} \mathrm{H}_{46} \mathrm{CoF}_{12} \mathrm{~N}_{8} \mathrm{OP}_{2}$ $\left(\mathbf{C 6} \cdot \mathrm{CH}_{3} \mathrm{COCH}_{3}\right): \mathrm{C}, 48.48 ; \mathrm{H}, 4.56 ; \mathrm{N}, 11.03$. Found: $\mathrm{C}, 48.32 ; \mathrm{H}, 4.50 ; \mathrm{N}, 10.93$. LRMS $\left(\mathrm{ESI}^{+}\right), m / z: 812.3\left(\left[\mathrm{M}-\mathrm{PF}_{6}\right]^{+}\right), 333.7\left(\left[\mathrm{M}-2 \mathrm{PF}_{6}\right]^{2+}\right)$.

C7: Isolated yield: $88 \%$; ${ }^{1} \mathrm{H}-\mathrm{NMR}\left(300 \mathrm{MHz}, \mathrm{CD}_{3} \mathrm{CN}\right): 61.01,58.65,45.21,8.87,7.07,-7.92$; IR (ATR) $v_{\max }\left(\mathrm{cm}^{-1}\right): 2933$ (w), 2895 (w), 2818 (w), $1610(\mathrm{w}), 1573$ (w), 1521 (m), $1506(\mathrm{w})$, $1489($ w), 1436 (w), 1417 (w), 1384 (w), 1369 (w), $1311($ (w), $1271($ (w), 1232 (w), $1186($ w), 
$1166($ w), 1143 (w), $1126($ w), $1105(w), 1066$ (w), 1047 (w), 985 (w), 829 (s), $813($ s), $738(w)$,

694 (w); Anal. Calcd for $\mathrm{C}_{42} \mathrm{H}_{50} \mathrm{CoF}_{12} \mathrm{~N}_{10} \mathrm{P}_{2}$ : C, 48.33; H, 4.83; N, 13.42. Found: C, 47.89; H, 4.89; N, 13.30. LRMS (ESI $\left.{ }^{+}\right), m / z: 898.8\left(\left[\mathrm{M}-\mathrm{PF}_{6}\right]^{+}\right), 376.3\left([\mathrm{M}-2 \mathrm{PF} 6]^{2+}\right)$.

C8: Isolated yield: $74 \%$; ${ }^{1} \mathrm{H}-\mathrm{NMR}\left(300 \mathrm{MHz}, \mathrm{CD}_{3} \mathrm{CN}\right)$ : 87.28, 67.31, 29.45, 19.16, 1.76, 9.82; IR (ATR) $v_{\max }\left(\mathrm{cm}^{-1}\right): 2972(\mathrm{w}), 2931(\mathrm{w}), 2893(\mathrm{w}), 2818(\mathrm{w}), 1608(\mathrm{~m}), 1537(\mathrm{w}), 1506$ (m), $1427(w), 1367(w), 1232(w), 1178(w), 1155(w), 1045(w), 989(w), 821(s), 810(s), 707$ (w); UV-vis $\left(\mathrm{CH}_{3} \mathrm{CN}\right)$ : ; Anal. Calcd for $\mathrm{C}_{46} \mathrm{H}_{60} \mathrm{CoF}_{12} \mathrm{~N}_{12} \mathrm{P}_{2}$ : C, 48.90; H, 5.35; N, 14.88. Found: C, 46.76; H, 5.15; N, 14.29. LRMS (ESI $\left.{ }^{+}\right), m / z: 984.9\left(\left[\mathrm{M}_{-} \mathrm{PF}_{6}\right]^{+}\right), 420.1\left(\left[\mathrm{M}-2 \mathrm{PF}_{6}\right]^{2+}\right)$.

\section{ASSOCIATED CONTENT}

* Supporting Information

The Supporting Information is available free of charge on the ACS Publications website at DOI:

Synthetic procedures of L2-L6 and C1-C8; Crystallographic data of C1, C3-C8; NMR spectra of L2-L6 and C1C8; MS spectra of L2-L6 and C1-C8; UV-vis spectra of L1-L8 and C1-C8, Buried volume of C1-C8; Cyclic voltammetry experiments of $\mathbf{C 1}-\mathbf{C} 8$ for $\mathrm{Co}(\mathrm{III} / \mathrm{II})$ couple; Computational details of $\mathbf{C 1}-\mathbf{C 8}$.

\section{ACKNOWLEDGEMENTS}

We acknowledge support from Foundation de l'Orangerie for individual Philanthropy and its donors. This work was supported by the French National Research Agency (ANR, Carbiored ANR-12-BS07-0024-03). This work has benefited from the facilities and expertise of the Small Molecule Mass Spectrometry platform of ICSN (Centre de Recherche de Gif - www.icsn.cnrsgifffr). P. H and H. U. R acknowledge the Deutsche Forschungsgemeinschaft for support. The 
calculations were performed using the HPC resources of GENCI (TGCC) through Grant 2017810082.

\section{Author Contributions}

The manuscript was written through contributions of all authors. All authors have given approval to the final version of the manuscript. 


\section{REFERENCES}

1. (a) Shepard, S. G.; Fatur, S. M.; Rappe, A. K.; Damrauer, N. H., Highly Strained Iron(II) Polypyridines: Exploiting the Quintet Manifold To Extend the Lifetime of MLCT Excited States. J. Am. Chem. Soc. 2016, 138, 2949-2952; (b) Brown, D. G.; Sanguantrakun, N.; Schulze, B.; Schubert, U. S.; Berlinguette, C. P., Bis(tridentate) Ruthenium-Terpyridine Complexes Featuring Microsecond Excited-State Lifetimes. J. Am. Chem. Soc. 2012, 134, 12354-12357; (c) Lin, H. W.; Wang, Y. S.; Huang, Z. Y.; Lin, Y. M.; Chen, C. W.; Yang, S. H.; Wu, K. L.; Chi, Y.; Liu, S. H.; Chou, P. T., Origins of device performance in dicarboxyterpyridine Ru(II) dyesensitized solar cells. Phys. Chem. Chem. Phys. 2012, 14, 14190-14195.

2. (a) Yum, J. H.; Baranoff, E.; Kessler, F.; Moehl, T.; Ahmad, S.; Bessho, T.; Marchioro, A.; Ghadiri, E.; Moser, J. E.; Yi, C. Y.; Nazeeruddin, M. K.; Gratzel, M., A cobalt complex redox shuttle for dye-sensitized solar cells with high open-circuit potentials. Nat. Commun. 2012, 3, 631; (b) Sapp, S. A.; Elliott, C. M.; Contado, C.; Caramori, S.; Bignozzi, C. A., Substituted polypyridine complexes of cobalt(II/III) as efficient electron-transfer mediators in dye-sensitized solar cells. J. Am. Chem. Soc. 2002, 124, 11215-11222; (c) Hamann, T. W., The end of iodide?

Cobalt complex redox shuttles in DSSCs. Dalton. Trans. 2012, 41, 3111-3115; (d) Stergiopoulos, T.; Falaras, P., Minimizing Energy Losses in Dye-Sensitized Solar Cells Using Coordination Compounds as Alternative Redox Mediators Coupled with Appropriate Organic Dyes. Adv Energy Mater 2012, 2, 616-627.

3. Sevov, C. S.; Fisher, S. L.; Thompson, L. T.; Sanford, M. S., Mechanism-Based Development of a Low-Potential, Soluble, and Cyclable Multielectron Anolyte for Nonaqueous Redox Flow Batteries. J. Am. Chem. Soc. 2016, 138, 15378-15384. 
4. Fermi, A.; Bergamini, G.; Roy, M.; Gingras, M.; Ceroni, P., Turn-on Phosphorescence by Metal Coordination to a Multivalent Terpyridine Ligand: A New Paradigm for Luminescent Sensors. J. Am. Chem. Soc. 2014, 136, 6395-6400.

5. $\quad$ Li, C.; Fan, W.; Straus, D. A.; Lei, B.; Asano, S.; Zhang, D. H.; Han, J.; Meyyappan, M.; Zhou, C. W., Charge Storage Behavior of Nanowire Transistors Functionalized with Bis(terpyridine)-Fe(II) Molecules: Dependence on Molecular Structure. J. Am. Chem. Soc. 2004, $126,7750-7751$.

6. (a) Zheng, Z. K.; Opilik, L.; Schiffmann, F.; Liu, W.; Bergamini, G.; Ceroni, P.; Lee, L. T.; Schutz, A.; Sakamoto, J.; Zenobi, R.; VandeVondele, J.; Schluter, A. D., Synthesis of TwoDimensional Analogues of Copolymers by Site-to-Site Transmetalation of Organometallic Monolayer Sheets. J. Am. Chem. Soc. 2014, 136, 6103-6110; (b) Groger, G.; Meyer-Zaika, W.; Bottcher, C.; Grohn, F.; Ruthard, C.; Schmuck, C., Switchable Supramolecular Polymers from the Self-Assembly of a Small Monomer with Two Orthogonal Binding Interactions. J. Am. Chem. Soc. 2011, 133, 8961-8971; (c) Schubert, U. S.; Eschbaumer, C., Macromolecules containing bipyridine and terpyridine metal complexes: Towards metallosupramolecular polymers. Angew. Chem. Int. Edit. 2002, 41, 2892-2926.

7. Tan, J. Y.; Li, R.; Li, D. D.; Zhang, Q.; Li, S. L.; Zhou, H. P.; Yang, J. X.; Wu, J. Y.; Tian, Y. P., Thiophene-based terpyridine and its zinc halide complexes: third-order nonlinear optical properties in the near-infrared region. Dalton. Trans. 2015, 44, 1473-1482.

8. (a) Elgrishi, N.; Chambers, M. B.; Fontecave, M., Turning it off! Disfavouring hydrogen evolution to enhance selectivity for $\mathrm{CO}$ production during homogeneous $\mathrm{CO}_{2}$ reduction by cobalt-terpyridine complexes. Chem. Sci. 2015, 6, 2522-2531; (b) Elgrishi, N.; Griveau, S.; Chambers, M. B.; Bedioui, F.; Fontecave, M., Versatile functionalization of carbon electrodes 
with a polypyridine ligand: metallation and electrocatalytic $\mathrm{H}^{+}$and $\mathrm{CO}_{2}$ reduction. Chem. Commun. 2015, 51, 2995-2998.

9. Elgrishi, N.; Chambers, M. B.; Artero, V.; Fontecave, M., Terpyridine complexes of first row transition metals and electrochemical reduction of $\mathrm{CO}_{2}$ to CO. Phys. Chem. Chem. Phys. 2014, 16, 13635-13644.

10. Colombe, J. R.; Bernhardt, S.; Stathakis, C.; Buchwald, S. L.; Knochel, P., Synthesis of Solid 2-Pyridylzinc Reagents and Their Application in Negishi Reactions. Org. Lett. 2013, 15, $5754-5757$.

11. Morgan, G. T.; Burstall, F. H., 3. Dehydrogenation of Pyridine of Anhydrous Ferric Chloride. J. Chem. Soc. 1932, 20-30.

12. (a) Rosevear, P. E.; Sasse, W. H. F., Synthesis of some 4,4',4"-trialkyl-2,2'6',2"terpyridyls. J. Heterocyclic Chem. 1971, 8, 483-485; (b) Ben Hadda, T.; Le Bozec, H., Synthesis and characterization of ruthenium(II) complexes containing the new tridentate ligand 4,4',4"-tritert-butyl-terpyridine. Inorg. Chim. Acta 1993, 204, 103-107; (c) Robo, M. T.; Prinsell, M. R.; Weix, D. J., 4,4 ',4 "-Trimethy1-2,2 ':6 ',2 "-terpyridine by Oxidative Coupling of 4-Picoline. $J$. Org. Chem. 2014, 79, 10624-10628.

13. Sasaki, I.; Daran, J. C.; Balavoine, G. G. A., An Effective Route to Polysubstituted Symmetric Terpyridines. Synthesis 1999, 1999, 815-820.

14. (a) Louerat, F.; Gros, P. C., Functional polypyridine ligands from copper-mediated room temperature coupling of 4-chloro-2-trimethylsilylpyridine. Tetrahedron Lett. 2010, 51, 35583560; (b) Harzmann, G. D.; Neuburger, M.; Mayor, M., 4,4-Disubstituted Terpyridines and Their Homoleptic Fe ${ }^{\mathrm{II}}$ Complexes. Eur. J. Inorg. Chem. 2013, 2013, 3334-3347; (c) Cardenas, D. J.; Sauvage, J. P., Improved Synthesis of 2,6-Oligopyridines by Stille Cross-coupling Reaction. 
Synlett 1996, 1996, 916-918; (d) Schubert, U. S.; Eschbaumer, C., New Synthetic Strategy toward Pyridine-Based Ligands for Supramolecular Chemistry Utilizing 2,6Bis(trimethyltin)pyridine as the Central Building Block. Org. Lett. 1999, 1 , 1027-1029.

15. (a) Hommes, P.; Fischer, C.; Lindner, C.; Zipse, H.; Reissig, H. U., Unprecedented Strong Lewis Bases-Synthesis and Methyl Cation Affinities of Dimethylamino-Substituted Terpyridines. Angew. Chem. Int. Edit. 2014, 53, 7647-7651; (b) Hommes, P.; Reissig, H.-U., Synthesis and Photophysical Properties of Substituted 2,2':6',2"-Terpyridine Derivatives and Analogous Compounds with a Central Thiophene Ring. Asian. J. Org. Chem. 2016, 5, 10331040; (c) De Rache, A.; Gueddouda, N. M.; Bourdoncle, A.; Hommes, P.; Reissig, H. U.; Mergny, J. L., A Flexible Terpyridine Derivative Interacts Specifically with G-Quadruplexes. Chem. Eur. J. 2016, 22, 12651-12654.

16. Arana, C.; Yan, S.; Keshavarzk, M.; Potts, K. T.; Abruna, H. D., Electrocatalytic Reduction of Carbon Dioxide with Iron, Cobalt, and Nickel Complexes of Terdentate Ligands. Inorg. Chem. 1992, 31, 3680-3682.

17. (a) Poater, A.; Ragone, F.; Giudice, S.; Costabile, C.; Dorta, R.; Nolan, S. P.; Cavallo, L., Thermodynamics of N-Heterocyclic Carbene Dimerization: The Balance of Sterics and Electronics. Organometallics 2008, 27, 2679-2681; (b) Poater, A.; Cosenza, B.; Correa, A.; Giudice, S.; Ragone, F.; Scarano, V.; Cavallo, L., SambVca: A Web Application for the Calculation of the Buried Volume of N-Heterocyclic Carbene Ligands. Eur. J. Inorg. Chem. 2009, 2009, 1759-1766.

18. Chambers, J.; Eaves, B.; Parker, D.; Claxton, R.; Ray, P. S.; Slattery, S. J., Inductive influence of 4'-terpyridyl substituents on redox and spin state properties of iron(II) and cobalt(II) bis-terpyridyl complexes. Inorg. Chim. Acta 2006, 359, 2400-2406. 
19. Henderson, I. M.; Hayward, R. C., Substituent effects on the stabilities of polymeric and small molecule bis-terpyridine complexes. Polym. Chem. 2012, 3, 1221-1230.

20. England, J.; Bill, E.; Weyhermuller, T.; Neese, F.; Atanasov, M.; Wieghardt, K., Molecular and Electronic Structures of Homoleptic Six-Coordinate Cobalt(I) Complexes of 2,2':6',2"-Terpyridine, 2,2'-Bipyridine, and 1,10-Phenanthroline. An Experimental and Computational Study. Inorg. Chem. 2015, 54, 12002-12018.

21. Vargas, A.; Krivokapic, I.; Hauser, A.; Daku, L. M. L., Towards accurate estimates of the spin-state energetics of spin-crossover complexes within density functional theory: a comparative case study of cobalt(II) complexes. Phys. Chem. Chem. Phys. 2013, 15, 3752-3763.

22. (a) Kilner, C. A.; Halcrow, M. A., An unusual discontinuity in the thermal spin transition in $\left[\mathrm{Co}(\text { terpy })_{2}\right]\left[\mathrm{BF}_{4}\right]_{2}$. Dalton. Trans. 2010, 39, 9008-9012; (b) Enachescu, C.; Krivokapic, I.; Zerara, M.; Real, J. A.; Amstutz, N.; Hauser, A., Optical investigation of spin-crossover in cobalt(II) bis-terpy complexes. Inorg. Chim. Acta 2007, 360, 3945-3950; (c) Kremer, S.; Henke, W.; Reinen, D., High-Spin-Low-Spin Equilibria of Cobalt(2+) in the Terpyridine Complexes Co(terpy) ${ }_{2} \mathrm{X}_{2} \cdot \mathrm{nH}_{2} \mathrm{O}$. Inorg. Chem. 1982, 21, 3013-3022.

23. APEX 2, SAINT and SADABS Bruker AXS Inc.: Madison, Wisconsin, USA, 2009.

24. Sheldrick, G. M. SHELXTL 2014/7; University of Göttingen, Germany: 2014.

25. Zhao, Y.; Truhlar, D. G., A new local density functional for main-group thermochemistry, transition metal bonding, thermochemical kinetics, and noncovalent interactions. J. Chem. Phys. 2006, 125, 194101-194118.

26. (a) Mclean, A. D.; Chandler, G. S., Contracted Gaussian basis sets for molecular calculations. I. Second row atoms, $Z=11-18$. J. Chem. Phys. 1980, 72, 5639-5648; (b) Krishnan, 
R.; Binkley, J. S.; Seeger, R.; Pople, J. A., Self-consistent molecular orbital methods .XX. A basis set for correlated wave functions. J. Chem. Phys. 1980, 72, 650-654.

27. Frisch, M. J.; Trucks, G. W.; Schlegel, H. B.; Scuseria, G. E.; Robb, M. A.; Cheeseman, J. R.; Scalmani, G.; Barone, V.; Mennucci, B.; Petersson, G. A.; Nakatsuji, H.; Caricato, M.; Li, X.; Hratchian, H. P.; Izmaylov, A. F.; Bloino, J.; Zheng, G.; Sonnenberg, J. L.; Hada, M.; Ehara, M.; Toyota, K.; Fukuda, R.; Hasegawa, J.; Ishida, M.; Nakajima, T.; Honda, Y.; Kitao, O.; Nakai, H.; Vreven, T.; Montgomery Jr., J. A.; Peralta, J. E.; Ogliaro, F.; Bearpark, M. J.; Heyd, J.; Brothers, E. N.; Kudin, K. N.; Staroverov, V. N.; Kobayashi, R.; Normand, J.; Raghavachari, K.; Rendell, A. P.; Burant, J. C.; Iyengar, S. S.; Tomasi, J.; Cossi, M.; Rega, N.; Millam, N. J.; Klene, M.; Knox, J. E.; Cross, J. B.; Bakken, V.; Adamo, C.; Jaramillo, J.; Gomperts, R.; Stratmann, R. E.; Yazyev, O.; Austin, A. J.; Cammi, R.; Pomelli, C.; Ochterski, J. W.; Martin, R. L.; Morokuma, K.; Zakrzewski, V. G.; Voth, G. A.; Salvador, P.; Dannenberg, J. J.; Dapprich, S.; Daniels, A. D.; Farkas, Ö.; Foresman, J. B.; Ortiz, J. V.; Cioslowski, J.; Fox, D. J. Gaussian 09, Gaussian, Inc.: Wallingford, CT, USA, 2009.

28. Dolg, M.; Wedig, U.; Stoll, H.; Preuss, H., Energy- adjusted ab initio pseudopotentials for the first row transition elements. J. Chem. Phys. 1987, 86, 866-872. 


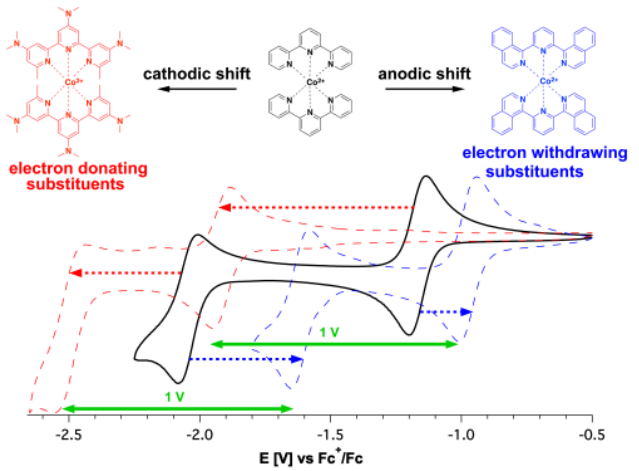

\section{For Table of Contents Only}

Synopsis. Synthesis of terpyridyl ligands with different electronic substituents was successfully achieved using the Stille cross-coupling reaction. The corresponding cobalt(II) bisterpyridyl molecular complexes were obtained and characterized by X-ray crystallography, spectroscopy and density functional theory calculations. The electronic substituents on the ligands allow tuning the reductions up to $1 \mathrm{~V}$. 